\title{
Relating sensory and chemical properties of sour cream to consumer acceptance
}

\author{
L. Shepard, R. E. Miracle, P. Leksrisompong, and M. A. Drake ${ }^{1}$ \\ Department of Food, Bioprocessing and Nutrition Sciences, Southeast Dairy Foods Research Center, North Carolina State University, \\ Raleigh 27695
}

\section{ABSTRACT}

Sour cream is a widely popular acidified dairy product. Volatile compounds and organic acids and their specific contributions to flavor or acceptance have not been established, nor has a comprehensive study been conducted to characterize drivers of liking for sour cream. The objective of this study was to characterize chemical and sensory properties of sour cream and to determine the drivers of liking for sour cream. Descriptive sensory and instrumental analyses followed by consumer testing were conducted. Flavor and texture attributes of 32 (22 full-fat, 6 reduced-fat, and 4 fat-free) commercial sour creams were evaluated by a trained descriptive sensory panel. Percent solids, percent fat, $\mathrm{pH}$, titratable acidity, and colorimetric measurements were conducted to characterize physical properties of sour creams. Organic acids were evaluated by HPLC and volatile aroma active compounds were evaluated by gas chromatography-mass spectrometry with gas chromatography-olfactometry. Consumer acceptance testing $(\mathrm{n}=201)$ was conducted on selected sour creams, followed by external preference mapping. Full-fat sour creams were characterized by the lack of surface gloss and chalky textural attributes, whereas reduced-fat and fat-free samples displayed high intensities of these attributes. Full-fat sour creams were higher in cooked/milky and milk fat flavors than the reducedfat and fat-free samples. Reduced-fat and fat-free sour creams were characterized by cardboard, acetaldehyde/ green, and potato flavors, bitter taste, and astringency. Lactic acid was the prominent organic acid in all sour creams, followed by acetic and citric acids. High aromaimpact volatile compounds in sour creams were 2,3-butanedione, acetic acid, butyric acid, octanal, 2-methyl3-furanthiol, 1-octene-3-one, and acetaldehyde. Positive drivers of liking for sour cream were milk fat, cooked/ milky and sweet aromatic flavors, opacity, color intensity, and adhesiveness. This comprehensive study

Received October 28, 2012.

Accepted June 2, 2013.

${ }^{1}$ Corresponding author: mdrake@unity.ncsu.edu established sensory and instrumental properties of sour creams and their relationship to consumer acceptance. Key words: sour cream, flavor, preference mapping

\section{INTRODUCTION}

In 2010, over 500 million kilograms of sour cream were produced in the United States (USDA-NASS, 2010). Sour cream is a fermented dairy product that is defined as the souring of pasteurized cream by lactic acid-producing bacteria (US FDA, 2011). In sour cream, the microorganisms used are Lactococcus lactis ssp. lactis, Lactococcus lactis ssp. cremoris, Cit + Lc. lactis ssp. lactis, and Leuconostoc citrovorum (MeunierGoddik, 2004). Different types of sour creams exist that are defined based on fat content. Full-fat sour creams must have at least 18\% milk fat and not less than $14.4 \%$ milk fat (USDA-AMS, 2005). Reduced-fat sour cream has a minimum fat reduction of $25 \%$ (USDA-AMS, 2005). Light or lite sour cream has a minimum of $50 \%$ fat reduction (USDA-AMS, 2005). Low-fat sour cream must contain $3 \mathrm{~g}$ or less fat per $50 \mathrm{~g}$ and $6 \%$ or less total fat (USDA-AMS, 2005). Nonfat sour cream must have less than $0.5 \mathrm{~g}$ of fat per $50 \mathrm{~g}$ of product and less than $1 \%$ total fat (USDA-AMS, 2005).

Lactic acid and other organic acids found in fermented dairy products are usually produced by one of the following: direct addition of an acidulant, normal bovine biochemical metabolism, hydrolysis of milk fat, or bacterial growth (Marsili et al., 1981). Acetic, butyric, citric, formic, hippuric, lactic, orotic, propionic, pyruvic, and uric are the most common organic acids in fermented dairy products. Many studies have been conducted to examine the concentrations of these organic acids in fermented dairy products, including cheese (Izco et al., 2002; Tormo and Izco, 2004), yogurt (Marsili et al., 1981; Bevilacqua and Califano, 1989; Fernandez-Garcia and McGregor, 1994), kefir (Marsili et al., 1981), and sour cream (Marsili et al., 1981). Most of these organic acids are not volatile and as such are not aroma active, but they do display distinct taste profiles (Marsili et al., 1981). Their specific contributions to sour cream flavor or acceptance are not known. 
Flavor plays a critical role in the acceptance of any product. Therefore, flavor is often investigated by descriptive analysis and consumer acceptance testing. Preference mapping is a collection of multivariate techniques used to establish relationships between instrumental and descriptive results and consumer acceptance data (Meilgaard et al., 2007). Preference mapping has been applied to examine the drivers of liking for many dairy products, including drinkable strawberry yogurt (Thompson et al., 2007), Cheddar cheese (Drake et al., 2008, 2009), Gouda cheese (Yates and Drake, 2007), and cottage cheese (Drake et al., 2009). Meunier-Goddik (2004) described sour cream as a heavy, viscous, glossy product that has a delicate lactic acid taste with a balanced, pleasant, buttery-like (diacetyl) aroma, but a complete sensory understanding of this important cultured dairy product has not been established. Volatile compounds and organic acids and their specific contributions to flavor or acceptance have not been established, nor has a comprehensive study been conducted to characterize drivers of liking. Such information would provide insight and direction for manufacturers and product developers. The objective of this study was to characterize sensory and chemical properties of sour cream and to determine the drivers of liking for sour cream. Descriptive analysis and instrumental analyses followed by consumer testing were conducted.

\section{MATERIALS AND METHODS}

\section{Sour Creams}

Commercial sour creams $(\mathrm{n}=32)$ were collected from across the United States. Sour creams were collected based on market share as well as fat content (full fat $=22$, light $=6$, and fat free $=4$ ). National, regional, and store brands were included. Regular, all-natural (no stabilizers), and organic products were included. Samples were received by overnight carrier on ice packs and were examined for damage and discarded if necessary. Products were stored in the dark at $4^{\circ} \mathrm{C}$. Each product was analyzed no later than $21 \mathrm{~d}$ before the expiration date. Duplicate lots of each brand were obtained approximately 1 mo apart.

\section{Composition Analysis}

Proximate analysis and color measurements were conducted on all sour creams. Sour creams were analyzed for TS and fat using the SMART Trac system (CEM Microwave Technology, Matthews, NC). Hunter $\mathrm{L}^{*} \mathrm{a}{ }^{*} \mathrm{~b}^{*}$ color scale analysis (where $\mathrm{L}^{*}=$ lightness, $\mathrm{a}^{*}$ $=$ position between red/magenta and green, and $\mathrm{b}^{*}=$ position between yellow and blue) was conducted using a Minolta Chroma meter (CR-410; Minolta, Ramsey, NJ). Ten grams of sour cream was placed into a 60$\times$ 15-mm polystyrene Petri dish (Becton Dickinson, Franklin Lakes, NJ); each Petri dish was measured in duplicate. A method from Wehr and Frank (2004) was used to measure titratable acidity. Measurements for $\mathrm{pH}$ were conducted with a $\mathrm{pH}$ meter (Mettler-Toledo GmbH, Schwerzenbach, Switzerland) with a combination electrode probe (BNC; Corning Inc., Corning, NY) at $4^{\circ} \mathrm{C}$. All compositional analyses were conducted in duplicate.

\section{Descriptive Analysis}

Sensory testing was conducted in compliance with the North Carolina State University Institutional Review Board for Human Subjects (Raleigh) approval. Sour creams (30 g) were scooped (size $30 \mathrm{scoop}$ ) into lidded 60-g soufflé cups with 3-digit codes and tempered to $15^{\circ} \mathrm{C}$. Each sample was served monadically with roomtemperature deionized water and unsalted crackers.

A trained descriptive sensory panel $(\mathrm{n}=8 ; 8$ females, ages 23 to $47 \mathrm{yr}$ ) evaluated the flavor, texture, and appearance attributes of sour creams using a 0- to 15-point universal intensity (flavor) or product-specific (visual and texture) scale (Meilgaard et al., 1999). Each panelist had more than $200 \mathrm{~h}$ of experience with descriptive analysis of flavor and approximately $100 \mathrm{~h}$ of experience with descriptive analysis of texture with various dairy products, including cheese and yogurt. Sour cream attributes were generated across four 2-h sessions where panelists tasted an array of sour creams as well as other cultured dairy products (yogurt and buttermilk) and discussed and generated terms and definitions. The lexicon generated for sour creams included 4 appearance, 11 flavor, 4 basic taste, 2 chemical feeling factor, and 6 texture attributes (Tables 1 and 2). Following lexicon generation, seven 3 -h sessions were held to refine the lexicon and to allow the panel to calibrate and consistently identify and score the attributes. Each sample from each lot (32 samples, with duplicate lots of each sample) was evaluated in duplicate by each panelist. Compusense Five (version 5.2; Compusense, Guelph, ON, Canada) or paper ballots were used for data collection (Swaney-Stueve and Heymann, 2002).

\section{Organic Acid Extraction and Separation}

A modified method from Marsili et al. (1981) was used for organic acid extraction of sour creams. Four grams was weighed into a $25-\mathrm{mL}$ volumetric flask. The sample was diluted with $0.01 \mathrm{~N}$ sulfuric acid $(2.0 \mathrm{~N}$; Mallinckrodt Baker Inc., Phillipsburg, NJ) and shaken 
Table 1. Flavor attributes for sour creams ${ }^{1}$

\begin{tabular}{|c|c|c|c|}
\hline Descriptor & Definition & Reference & Preparation \\
\hline Overall aroma & The overall orthonasal aroma impact & Not applicable & $\begin{array}{l}\text { Evaluated as the lid is removed from the } \\
\text { cupped sample }\end{array}$ \\
\hline Sour aromatic & Sour aromatics associated with fermented dairy products & Plain yogurt & $\begin{array}{l}\text { A } 225-\mathrm{mL} \text { amber sniff jar with } 100 \mathrm{mg} / \mathrm{kg} \\
\text { of acetaldehyde }\end{array}$ \\
\hline Sweet aromatic & Sweet aromatic associated with sweet smelling foods & Ricotta cheese & $\begin{array}{l}\text { A table spoon of ricotta cheese in a } 58 \text { - } \\
\text { mL lidded soufflé cup }\end{array}$ \\
\hline Acetaldehyde/green & Aromatics reminiscent of green apples & Acetaldehyde at $100 \mathrm{mg} / \mathrm{kg}$ or plain yogurt & $\begin{array}{l}\text { A } 225-\mathrm{mL} \text { amber sniff jar with } 100 \mathrm{mg} / \mathrm{kg} \\
\text { of acetaldehyde }\end{array}$ \\
\hline Cooked/milky & Aromatics associated cooked milk & Cooked milk & $\begin{array}{l}1 \text { ounce of heated milk in a } 60-\mathrm{mL} \text { soufflé } \\
\text { cup }\end{array}$ \\
\hline Cooked/sulfur/beefy & $\begin{array}{l}\text { Aromatics associated with sulfurous compounds } \\
\text { or beef stock }\end{array}$ & $\begin{array}{l}\text { Boiled mashed egg or struck match, } \\
\text { 2-methyl-3-furanthiol }\end{array}$ & $\begin{array}{l}\text { Eggs were boiled and mashed and } 10 \mathrm{~g} \\
\text { placed in a } 58 \text {-mL soufflé cup. A 225- } \\
\text { mL amber sniff jar with } 100 \mathrm{mg} / \mathrm{kg} \text { of } \\
\text { 2-methl-3-furanthiol }\end{array}$ \\
\hline Diacetyl & Aromatics reminiscent of diacetyl & Diacetyl & $\begin{array}{l}\text { A } 225-\mathrm{mL} \text { amber sniff jar with } 100 \mathrm{mg} / \\
\mathrm{kg} \text { of diacetyl }\end{array}$ \\
\hline Milk fat & Aromatics associated with milk fat & $\begin{array}{l}\text { Fresh coconut meat, heavy cream, or } \\
\delta \text {-decalactone }\end{array}$ & $\begin{array}{l}\text { A } 225 \text {-mL amber sniff jar with } 500 \mathrm{mg} / \mathrm{kg} \\
\text { of } \delta \text {-decalactone }\end{array}$ \\
\hline Potato & Aromatics associated with canned potato & Methional at $100 \mathrm{mg} / \mathrm{kg}$ & $\begin{array}{l}\text { A } 225-\mathrm{mL} \text { amber sniff jar with } 100 \mathrm{ppm} \\
\text { of methional }\end{array}$ \\
\hline Cardboard & Aromatics associated with cardboard & Wet cardboard & $\begin{array}{l}\text { Soak } 2 \mathrm{~cm} \text { square of cardboard in water } \\
\text { for } 30 \mathrm{~min}\end{array}$ \\
\hline FFA & Aromatic associated with short-chain FA & Feta cheese, butyric acid & $\begin{array}{l}\text { A } 225-\mathrm{mL} \text { amber sniff jar with } 100 \mathrm{mg} / \mathrm{kg} \\
\text { of butyric acid }\end{array}$ \\
\hline Sweet taste & Basic taste associated with sugars & Sucrose & $5 \%$ sucrose solution \\
\hline Salty taste & Basic taste associated with salts & $\mathrm{NaCl}$ & $2 \% \mathrm{NaCl}$ solution \\
\hline Bitter taste & Basic taste associated with various compounds & Caffeine & $0.5 \%$ caffeine solution \\
\hline Sour taste & Basic taste associated with acids & Citric acid & $0.08 \%$ citric acid solution \\
\hline Astringency & Drying or puckering of oral tissues & Black tea & Soak 6 tea bags in hot water for $10 \mathrm{~min}$ \\
\hline Fizziness & Burning/stinging sensation on the tongue & Carbonated soda water & $\begin{array}{l}30 \mathrm{~mL} \text { of carbonated soda water in a } 60- \\
\mathrm{mL} \text { soufflé cup }\end{array}$ \\
\hline
\end{tabular}

${ }^{1}$ Flavor attributes were scored using the 0 - to 15 -point spectrum intensity scale (Meilgaard et al., 1999). Most dairy product flavor attributes fall between 0 to 5 on this scale (Drake et al., 2008, 2009). 
for $1 \mathrm{~min}$ by hand. The sample was also vortexed for 20 $\mathrm{s}$ to ensure proper mixing. The sample was then centrifuged at 24,150 $\times g$ (Sorvall model RC-B5; Thermo Scientific, Waltham, MA) for 10 min and filtered using a 0.22-um PTEF membrane (VWR International LLC, West Chester, PA) and injected onto the HPLC (Waters 2996; Waters Inc., Milford, MA). All sour creams were extracted in duplicate.

The HPLC was equipped with a manual $10-\mu \mathrm{L}$ loop injector, photodiode array detector (2996; Waters Inc.), pump (515; Waters Inc.), inline degasser AF (Waters Inc.), and an insulated column oven. The software system used was Empower (Waters Inc.). The amount of sample injected was $10 \mu \mathrm{L}$. The mobile phase used was $0.01 \mathrm{~N}$ sulfuric acid (Mallinckrodt Baker Inc.). The flow rate was $0.7 \mathrm{~mL} / \mathrm{min}$ and the temperature of the column and guard column was $65^{\circ} \mathrm{C}$. Organic acids were identified by injecting authentic standards and comparing the retention times of the authentic standard. The column used was an Aminex HPX-87 H cation-exchange column $(300 \times 7.8 \mathrm{~mm}, 9-\mu \mathrm{m}$ particle size; Bio-Rad Laboratories Inc., Hercules, CA). The guard column used was a Cation H Cartridge (Bio-Rad Laboratories Inc.). All sour creams were extracted and injected in duplicate.

\section{Solid-Phase Microextraction: Gas Chromatography-Olfactometry}

Solid-phase microextraction (SPME) was conducted on all samples followed by gas chromatography-olfactometry (GC-O) for characterization of aroma active compounds. Ten grams of each sample along with $10 \%$ sodium chloride (wt/wt) was dispersed into six $40-\mathrm{mL}$ amber vials $(28 \times 98 \mathrm{~mm}$; Supelco Inc., Bellefonte, PA) with a polytetrafluoroethylene (PTFE)/silicone septum (Supelco Inc.) and a stir bar. The vials were heated at $40^{\circ} \mathrm{C}$ for $20 \mathrm{~min}$ with constant stirring. An SPME fiber [divinylbenzene/Carboxen/polydimethylsiloxane (DVB/CAR/PDMS); Supelco Inc.] was exposed in each sample at $1 \mathrm{~cm}$ for $30 \mathrm{~min}$. The fiber was then injected on an Agilent 6850 gas chromatography-flame ionization detector (FID) equipped with an olfactometer port (Agilent Technologies Inc., Santa Clara, CA) at $3 \mathrm{~cm}$. The GC method used an initial temperature of $40^{\circ} \mathrm{C}$ for $3 \mathrm{~min}$. The temperature was then increased at a rate of $10^{\circ} \mathrm{C} / \mathrm{min}$ to $150^{\circ} \mathrm{C}$, followed by $30^{\circ} \mathrm{C} / \mathrm{min}$ to $200^{\circ} \mathrm{C}$, and held for $5 \mathrm{~min}$. Samples were evaluated in duplicate on 2 different columns: polar ZB-WAX (30-m length $\times 0.25-\mathrm{mm}$ i.d. $\times 0.25-\mu \mathrm{m}$ film thickness; Zebron; Phenomenex Inc., Torrance, CA) and a nonpolar ZB-5ms $(30-\mathrm{m}$ length $\times 0.25-\mathrm{mm}$ i.d. $\times 0.25-\mu \mathrm{m}$ film thickness; Zebron; Phenomenex Inc.). Effluent was split 1:1 between the FID and sniffing port using deactivated 
fused-silica capillaries $(1$-m length $\times 0.25$-mm i.d.; Phenomenex Inc.). The FID sniffing port was held at a temperature of $300^{\circ} \mathrm{C}$, with a helium carrier gas flow of $1018.6 \mathrm{~cm} / \mathrm{s}$, and the port was supplied with humidified air at $30 \mathrm{~mL} / \mathrm{min}$. Each sample was evaluated by 2 highly experienced sniffers who recorded aroma character and perceived intensity.

\section{SPME: GC-MS}

All sour creams were evaluated by SPME-GC-MS for extraction and identification of volatile compounds. Each sour cream was evaluated in scan mode followed by selective ion monitoring (SIM) mode. Five milliliters of each sour cream along with $10 \%$ sodium chloride (wt/wt) was dispensed into three 20-mL autosampler vials with steel screw tops, containing silicon septa face in Teflon (Microliter Analytical Supplies, Suwannee, GA). An internal standard of 2-methyl-3-heptanone in methanol at $81 \mathrm{mg} / \mathrm{kg}$ (Sigma-Aldrich, St. Louis, MO) was added to the samples. The samples were then injected using a CTC Analytics Combi PAL autosampler (Leap Technologies, Carrboro, NC) attached to an Agilent 6890N GC-MS with inert 5973 MSD (Agilent Technologies Inc.). The SPME fiber contained 3 different phases (DVB/CAR/PDMS; Supelco Inc.). The column used was a nonpolar ZB-5ms (30-m length $\times$ 0.25 -mm i.d. $\times$ 0.25-um film thickness; Phenomenex Inc.). The GC method used an initial temperature of $40^{\circ} \mathrm{C}$ for $3 \mathrm{~min}$. The temperature was then increased at a rate of $10^{\circ} \mathrm{C} / \mathrm{min}$ to $90^{\circ} \mathrm{C}$, increased by $5^{\circ} \mathrm{C} / \mathrm{min}$ to $200^{\circ} \mathrm{C}$, and held for $10 \mathrm{~min}$. The temperature was then increased at a rate of $20^{\circ} \mathrm{C} / \mathrm{min}$ to $250^{\circ} \mathrm{C}$ and held for 5 min. The SPME fiber was introduced into the split/ splitless injector at $250^{\circ} \mathrm{C}$ at a pressure of $48.7 \mathrm{kPa}$, with helium as the carrier gas and a purge flow of 1,697 $\mathrm{cm} / \mathrm{s}$. A constant flow rate of $34 \mathrm{~cm} / \mathrm{s}$ was maintained. The purge time was $1 \mathrm{~min}$. The MS transfer line was maintained at $250^{\circ} \mathrm{C}$, with the quad at $150^{\circ} \mathrm{C}$ and the source at $250^{\circ} \mathrm{C}$.

\section{Identification of Odorants}

Positive identification of aroma active compounds was achieved using retention indices $(\mathbf{R I})$ on both GC columns, comparison of odor properties, and mass spectra of the unknowns against authentic standards or an evaluation of the literature. An $n$-alkane series (Fluka, Buchs, Switzerland) was used for the calculation of RI values (van Den Dool and Kratz, 1963).

\section{Compound Relative Abundance with SIM Mode}

All sour creams were subsequently evaluated by SPME-GC-MS using SIM mode. The SIM mode al- lowed for improved detection levels by focusing on unique ion(s) at a certain retention time of a compound of interest, ignoring other ions present within the sample. Compounds were selected for evaluation in SIM based on aroma activity from GC-O results. The unique ions for each compound were selected using the National Institute of Standards and Technology (NIST) Mass Spectral Search Program 2.0 (John Wiley \& Sons Inc., Hoboken, NJ) and injection of authentic standards. The data were analyzed using MS ChemStation software (Agilent Technologies Inc., Durham, NC). Relative abundance was calculated for each compound based on recovery of the internal standard.

\section{Consumer Acceptance Testing}

Representative commercial sour creams $(\mathrm{n}=12 ; 9$ full fat, 1 reduced fat, and 2 light) were selected for consumer acceptance testing based on examination of principal components biplots, product mean attributes, and market share. Samples were prepared in the same manner as for descriptive analysis, with the exception that samples were served at $4^{\circ} \mathrm{C}$. Consumer acceptance testing $(\mathrm{n}=201)$ was conducted over $4 \mathrm{~d}$. Sour cream users $(\mathrm{n}=201)$ were recruited from an online database maintained by the Sensory Service Center (North Carolina State University). The database consisted of 3,800 individuals from the Raleigh (NC) area recruited by newspaper and magazine advertisements. All consumers were the primary shoppers in their households and purchased as well as consumed sour cream. Consumers who participated were compensated with a $\$ 30$ Target gift card (Target Brands Inc., Minneapolis, MN). Six sour creams were tasted in each of 2 sessions on 2 consecutive days by each consumer $(\mathrm{n}=12$ total sour creams evaluated by each consumer).

For each session, consumers were provided with consent forms, consistent with human subjects approval, and a ballot. Each sour cream was scooped as each consumer arrived, using a 40-g scoop and placed in a 118-mL soufflé cup with a 3 -digit code. Spoons and napkins were provided. Compusense Five or paper ballots were used for data collection (Swaney-Stueve and Heymann, 2002). Consumers were first asked to evaluate overall appearance. The appearance of each sample was scaled using a 9-point hedonic scale, where $1=$ dislike extremely and $9=$ like extremely. They were then asked to taste the sample and evaluate their overall impression of the sample using the 9-point hedonic scale. Consumers were then asked to evaluate their liking of flavor on a 9-point hedonic scale and their perception of product freshness, where $1=$ not fresh at all and $9=$ extremely fresh. Consumers were then asked to evaluate sourness, texture, and thickness lik- 
ing using a hedonic 9-point scale. This was followed by just-about-right (JAR) questions on sourness, texture, creaminess, and smoothness, where 1 and $2=$ not sour enough, $3=$ just about right, and 4 and $5=$ too sour; 1 and $2=$ too thin, $3=$ just about right, and 4 and $5=$ too thin; 1 and $2=$ not creamy enough, $3=$ just about right, 4 and $5=$ too creamy; and 1 and $2=$ not smooth enough, $3=$ just about right, 4 and $5=$ too smooth, respectively. Consumers were then asked how likely they would be to purchase this product. They responded to this question using a 5-point scale, where $1=$ definitely would not buy and $5=$ definitely would buy. A 2-min rest was enforced between samples and consumers were instructed to drink spring water to rinse their palates.

\section{Statistical Analysis}

All statistical analyses were conducted with XLSTAT software (Addinsoft, New York, NY). Liking scores were evaluated by ANOVA with Fisher's post hoc test using. Just-about-right scores were evaluated using penalty and chi-square analysis. Purchase intent was evaluated using a Kruskal-Wallis test with Dunn's post hoc test. All statistics were calculated to 95\% confidence intervals. Descriptive analysis, volatile compound relative abundance, and organic acid concentrations were analyzed using ANOVA with Fisher's least significant difference test at $P \leq 0.05$ significance level. Descriptive analysis data was also analyzed using principal components analysis with varimax rotation. Consumer clusters were evaluated using k-means. Clusters were validated using discriminant analysis. Twoway ANOVA was conducted on samples and clusters for main effects and 2-way interactions. External preference mapping with consumer clusters was conducted using partial least squares regression on descriptive and consumer data. Correlation analysis with a Bonferroni correction was also conducted to determine individual relationships between sensory attributes and instrumental data.

\section{RESULTS AND DISCUSSION}

\section{Composition}

The amount of fat present in each sour cream was consistent with labels, as expected (Table 3). Sour creams 789,885 , and 951 were organic sour creams that had the highest color intensities and concurrently the highest $\mathrm{b}^{*}$ values (Table 3 ). Treatment 515 , a full-fat sour cream, had the lowest $\mathrm{pH}$ (3.81) of all sour creams (Table 3). All natural sour creams $(106,119,123,881$, 999, and 951) had the lowest percentage of lactic acid present.

\section{Descriptive Analysis}

All sour creams had the following attributes: overall aroma impact, sour aromatic, cooked/milky, cooked/ sulfurous/beefy, astringency, and sweet and sour tastes. These sensory attributes were due to the heat treatment of the product before fermentation or the lactic acid fermentation. Milk fat flavor was also present in sour creams, with the exception of fat-free products. Sour creams 665 and 654 were the only samples that had perceptible salty taste. Sour taste was the predominant sensory attribute among the sour creams, ranging from 1.1 to 5.2 on a 0 - to 15 -point universal scale, which is characteristic of fermented dairy products. A fat-free sour cream (775) had the highest intensity of bitter taste. Full-fat sour cream 335 was higher in milk fat flavor than other sour creams and it also had the highest fat content. The reduced-fat and fat-free sour creams contained higher intensities of sweet taste than the full-fat sour creams.

Principal components analysis was applied to visualize differences among the samples across all attributes (Figure 1). Principal component 1 (29\% variability) comprised overall aroma, green/acetaldehyde, cooked/ milky, milk fat, potato, cardboard, and FFA flavors, astringency, fizziness, and sweet and sour tastes, whereas principal component 2 (13\% variability) comprised sour aromatic, diacetyl and cooked/sulfurous/beefy flavors (Figure 1). Principal component 3 (10\% variability) comprised bitter taste and principal component $4(9 \%$ variability) comprised the sweet aromatic flavor (Figure 2). Reduced-fat and fat-free sour creams were characterized by cardboard, sweet taste, potato, and green/ acetaldehyde flavors (Figures 1 and 2), whereas full-fat sour creams were characterized by a lack of these flavors. All full-fat sour creams were characterized by milk fat, diacetyl, sour aromatic, cooked/milky, and cooked/ sulfurous/beefy flavor attributes (Figure 1).

Principal components analysis of textural and visual attributes explained $62 \%$ of the variability among the sour creams on 2 principal components (Figure 3). Principal component 1 comprised mouthcoating, color intensity, and opacity (Figure 3). Principal component 2 comprised surface grain, adhesiveness, surface gloss, slipperiness, and chalkiness (Figure 3). Full-fat sour creams were characterized by mouthcoating, opacity, adhesiveness, color intensity, firmness, and denseness, whereas reduced-fat and fat-free sour creams were characterized by chalkiness and surface gloss (Figure 3). The organic sour creams (951, 987, and 885) had higher color intensities than the nonorganic samples, possibly due to carotenoids present from grass feeding (Nozière et al., 2006). Full-fat sour creams had higher firmness intensities than reduced-fat and fat-free sour creams (20 
Table 3. $\mathrm{pH}$, total fat, TS, $\mathrm{L}^{*} \mathrm{a}^{*} \mathrm{~b}^{*}$ Hunter color scale values, and lactic acid concentration of sour creams ${ }^{1}$

\begin{tabular}{|c|c|c|c|c|c|c|c|}
\hline \multirow[b]{2}{*}{ Item } & \multirow[b]{2}{*}{$\mathrm{pH}$} & \multirow[b]{2}{*}{ Total fat ${ }^{2}$} & \multirow[b]{2}{*}{$\mathrm{TS}^{3}$} & \multicolumn{3}{|c|}{ Hunter color scale } & \multirow{2}{*}{$\begin{array}{c}\text { Lactic acid, } \\
\mathrm{g} \text { of lactic acid } \\
\text { equivalents } \\
\text { per } 10-\mathrm{g} \text { sample }\end{array}$} \\
\hline & & & & $\mathrm{L}^{*}$ & $a^{*}$ & $b^{*}$ & \\
\hline \multicolumn{8}{|c|}{ Sample } \\
\hline \multicolumn{8}{|c|}{ Full fat } \\
\hline 106 & 4.53 & 18.2 & 25.3 & 84.8 & -1.63 & 8.76 & 0.07 \\
\hline 111 & 4.55 & 17.7 & 25.1 & 83.3 & -1.69 & 8.73 & 0.08 \\
\hline 115 & 4.34 & 18.0 & 29.2 & 83.5 & -1.72 & 10.2 & 0.10 \\
\hline 121 & 4.67 & 18.6 & 27.6 & 84.5 & -2.09 & 9.41 & 0.09 \\
\hline 123 & 4.56 & 18.7 & 26.2 & 85.0 & -1.54 & 7.93 & 0.07 \\
\hline 321 & 4.67 & 17.7 & 26.0 & 84.9 & -1.65 & 9.89 & 0.08 \\
\hline 357 & 4.21 & 18.1 & 26.9 & 82.1 & -1.41 & 9.44 & 0.17 \\
\hline 363 & 4.47 & 17.9 & 26.6 & 84.8 & -2.10 & 9.92 & 0.09 \\
\hline 456 & 4.78 & 20.1 & 29.4 & 82.4 & -1.62 & 9.71 & 0.09 \\
\hline 464 & 4.82 & 18.0 & 26.9 & 83.6 & -1.64 & 9.06 & 0.17 \\
\hline 515 & 3.81 & 17.8 & 27.4 & 85.4 & -1.93 & 8.76 & 0.09 \\
\hline 996 & 4.46 & 18.4 & 26.4 & 83.9 & -1.66 & 9.60 & 0.08 \\
\hline 654 & 4.77 & 17.8 & 26.7 & 82.7 & -1.5 & 9.65 & 0.09 \\
\hline 665 & 4.67 & 22.2 & 29.6 & 84.4 & -1.87 & 10.0 & 0.10 \\
\hline 666 & 4.34 & 19.6 & 29.5 & 85.3 & -2.02 & 10.7 & 0.10 \\
\hline 753 & 4.71 & 22.1 & 33.0 & 84.6 & -1.2 & 7.68 & 0.09 \\
\hline 999 & 4.56 & 17.4 & 24.5 & 83.1 & -1.71 & 9.06 & 0.08 \\
\hline 779 & 4.74 & 16.8 & 26.3 & 84.7 & -2.16 & 10.0 & 0.09 \\
\hline 789 & 4.44 & 17.8 & 25.3 & 83.8 & -1.66 & 10.7 & 0.08 \\
\hline 881 & 4.54 & 18.0 & 26.4 & 83.4 & -1.62 & 9.81 & 0.08 \\
\hline 951 & 4.74 & 33.1 & 39.5 & 85.0 & -2.35 & 15.0 & 0.05 \\
\hline 888 & 4.83 & 17.7 & 27.2 & 83.5 & -1.69 & 8.73 & 0.09 \\
\hline \multicolumn{8}{|c|}{ Reduced fat } \\
\hline 335 & 4.38 & 25.5 & 32.2 & 83.9 & -1.65 & 10.5 & 0.10 \\
\hline 222 & 4.51 & 9.86 & 22.2 & 82.8 & -2.33 & 9.95 & 0.11 \\
\hline \multicolumn{8}{|l|}{ Light } \\
\hline 969 & 4.59 & 8.84 & 22.2 & 83.9 & -1.74 & 7.96 & 0.11 \\
\hline 987 & 4.65 & 6.72 & 20.3 & 83.9 & -2.65 & 12.3 & 0.10 \\
\hline 552 & 4.74 & 7.69 & 21.8 & 82.8 & -2.02 & 10.1 & 0.14 \\
\hline 885 & 4.61 & 5.98 & 21.1 & 82.1 & -1.86 & 11.0 & 0.12 \\
\hline \multicolumn{8}{|c|}{ Fat free } \\
\hline 333 & 4.67 & 1.41 & 22.3 & 82.9 & -2.72 & 8.83 & 0.10 \\
\hline 445 & 4.69 & 1.45 & 16.8 & 82.6 & -1.76 & 7.91 & 0.10 \\
\hline 555 & 4.74 & 0.83 & 19.5 & 81.2 & -2.07 & 9.50 & 0.17 \\
\hline 775 & 4.57 & 1.62 & 22.9 & 82.7 & -1.84 & 9.05 & 0.17 \\
\hline $\mathrm{LSD}^{4}$ & 0.030 & 1.82 & 0.24 & 0.94 & 0.14 & 0.22 & 0.0024 \\
\hline
\end{tabular}

full fat, 5 reduced fat and fat free). Sour creams 106, 123,881 , and 999 were full-fat all natural sour creams. All natural full-fat sour creams contained no stabilizers or thickeners and also had the lowest chalky intensities of the full-fat samples ( 0.5 to 0.8 for all-natural and not detected to 7.5 for all other sour creams).

\section{Organic Acids}

Organic acid concentrations were variable among sour creams (Table 4). Lactic acid was the predominant acid present, as expected. Pyruvic acid was not detected in 2 sour creams and 5 sour creams contained no detectable levels of butyric acid. Full-fat sour cream 464 had the highest amount of acetic acid present, whereas sample 357 had no detectable levels of acetic acid. Propionic acid was detected in 5 sour creams, and hippuric acid was only detected in 1 sour cream.

Citric acid occurs naturally in milk and is the most prevalent acid in raw milk (Urbiené and Leskauskaité, 2006). However, citric acid is also consumed by lactic acid bacteria during the fermentation process of dairy products (Urbiené and Leskauskaitė, 2006). Fermentation times for each sour cream may contribute to the amount and type of organic acids present. The end result of consumption of lactose by lactic acid bacteria 


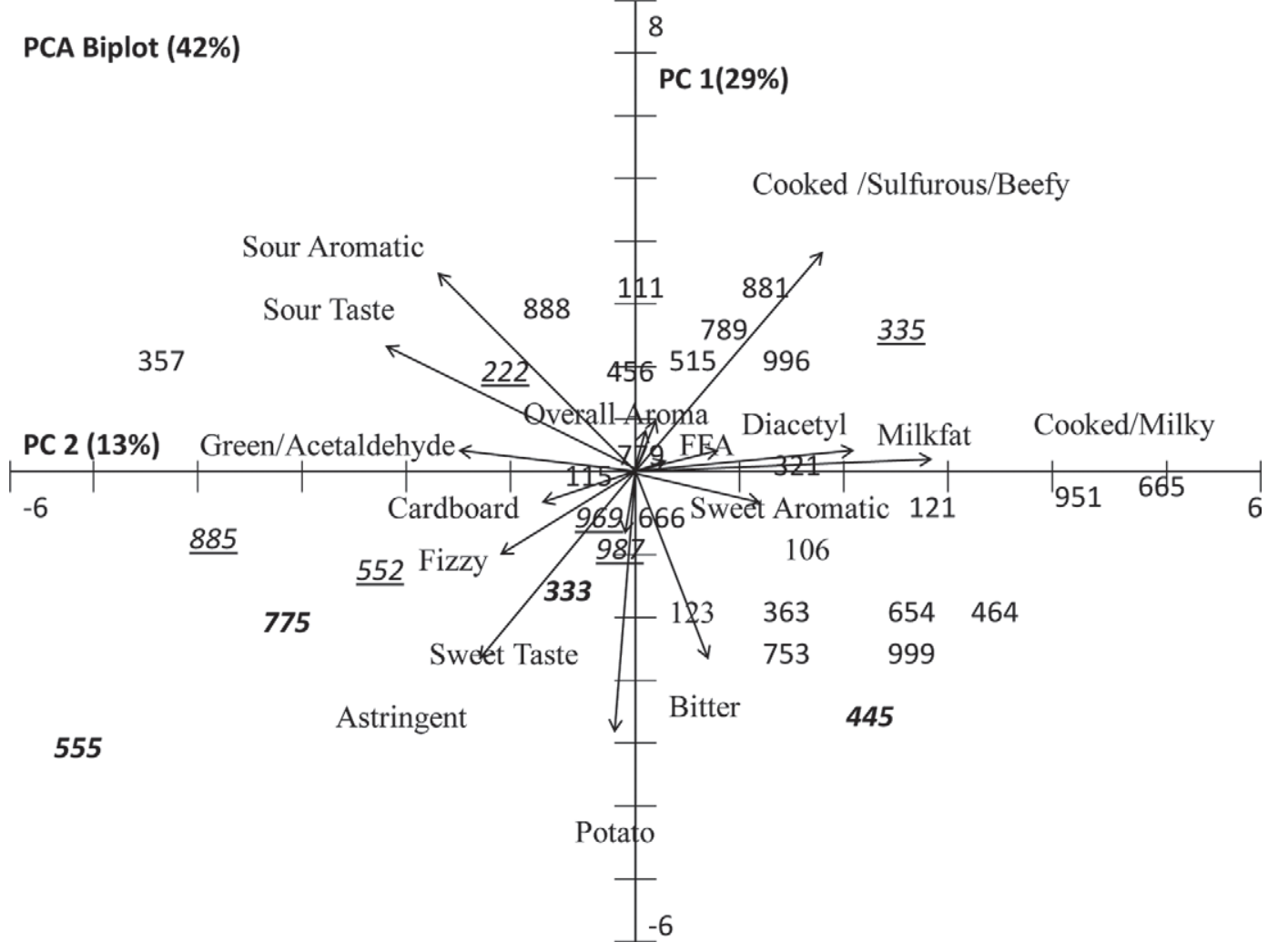

Figure 1. Principal components (PC) analysis (PCA) biplot (PC 1 and 2) of flavor attributes of sour creams. Full-fat sour creams are numbers, reduced-fat sour creams are underlined and italic numbers, and fat-free sour creams are bold numbers.

is acetic and lactic acids (Urbienè and Leskauskaité, 2006). As milk ferments, the concentrations of some acids, such as lactic, propionic, and acetic, increase and hippuric, orotic, and citric acids decrease (Dellaglio, 1988; Driessen and Puhan, 1988). Formic acid is naturally present in milk and is the end result of lactose consumed during the fermentation process (Zhang and Metzger, 2010). Propionic acid is either directly added as an acidulant or present due to bacteria growth (Marsili et al., 1981). Uric and orotic acids are naturally present in milk as a result of normal bovine biochemical metabolism (Zhang and Metzger, 2010). Lactic acid bacteria can convert hippuric acid into benzoic acid during fermentation (Hatanaka and Kaneda, 1986). Previous research has demonstrated that hippuric acid was not detected $4 \mathrm{~h}$ into the fermentation process of kefir (Fernandez-Garcia and McGregor, 1994), which may explain this acid being detected in only 1 sample and at a low level. Pyruvic acid is an intermediate compound that occurs in different metabolic pathways (Rysstad and Abrahamsen, 1987). Fernandez-Garcia and McGregor (1994) also found that pyruvic acid was present at its highest concentration in the sixth hour of fermentation of kefir and from there it continued to decrease.
Acetic and butyric acids, in addition to contributing sour taste, are also flavor-active compounds (Singh et al., 2003). Similar to acetic acid, butyric acid is also a product of lactose fermentation (Zhang et al., 2009). Acetic acid was present in the majority of the sour creams and likely contributed to (to some degree) the intensities of sour aromatic flavors present in sour creams. Whereas butyric acid was detected by instrumental analysis at a range of 30 to $810 \mathrm{mg} / \mathrm{kg}$ in the majority of the sour creams (27/32), FFA flavor was only detected by sensory analysis in a few sour creams $(8 / 32)$. This is likely due to the sensory threshold of butyric acid, which is in the milligrams per kilogram (ppm) range and varies with matrix (van Gemert, 2003).

Correlations analysis was conducted on $\mathrm{pH}$, titratable acidity, sour taste and organic acids and sour taste. Citric, formic, uric, orotic, pyruvic, butyric, and acetic acids were positively correlated with titratable acidity $(P<0.05)$. A negative correlation $(P<0.05)$ was found between lactic and pyruvic acids and $\mathrm{pH}$. No correlation $(P>0.05)$ existed between citric, formic, uric, orotic, butyric, and acetic acids and $\mathrm{pH}$. Sour aromatic flavor was positively correlated with citric and butyric acids $(\mathrm{r}=0.72$ and 0.76 , respectively; $P<0.05)$ 


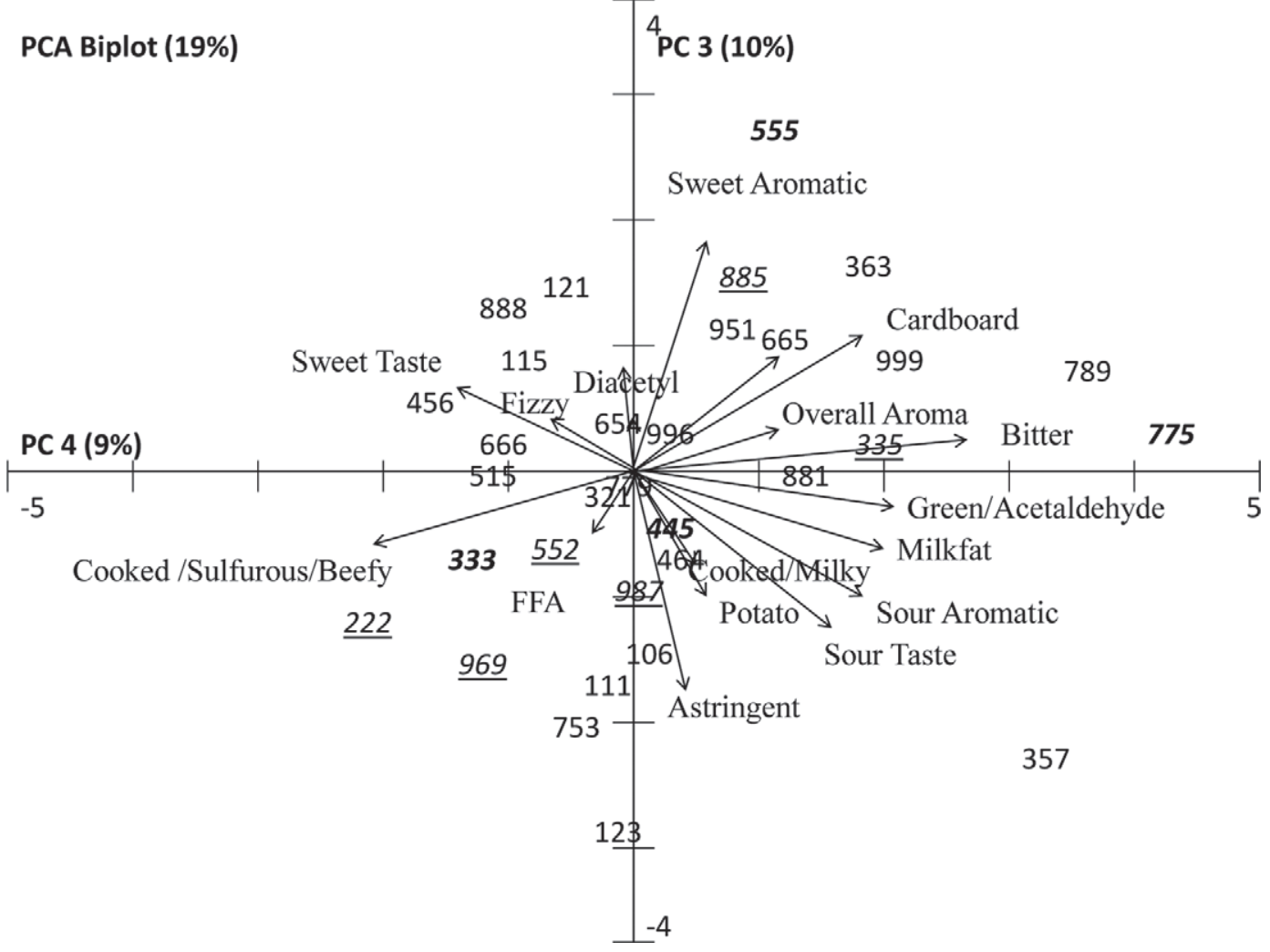

Figure 2. Principal components (PC) analysis (PCA) biplot (PC 3 and 4) of flavor attributes of sour creams. Full-fat sour creams are numbers, reduced-fat sour creams are underlined and italic numbers, and fat-free sour creams are bold numbers.

Green/acetaldehyde flavor was positively correlated with lactic, uric, and butyric acids $(\mathrm{r}=0.56,0.71$, and 0.70 , respectively; $P<0.05)$ and negatively correlated with acetic acid $(\mathrm{r}=-0.87 ; P<0.05)$.

\section{GC-O/MS Results}

Forty aroma active compounds were detected in sour creams by SPME-GC-O (Tables 5 and 6 ). Not all aroma compounds detected by SPME-G-CO were detected by GC-MS. The following aroma active compounds were not detected by GC-MS, but were detected by GCO: methyl ethyl sulfide, 2-isobutyl-3-methoxypyrazine, estragole, methyl-2-methyl-3-furyl disulfide, 2-octyl-furan, benzolthiazole, and o-aminoacetophenone. Thirtyfour compounds were positively identified by GC-MS, RI, and aroma (Tables 5-8). Seven compounds were tentatively identified by RI and odor compared with authentic standards or RI and odor compared with the published literature.

Seven of the 34 aroma compounds detected by GCMS (dimethyl trisulfide, 2-methyl-3-furanthiol, 1-hexen3-one, nonanal, dimethyl sulfide, 1-octene-3-one, and acetaldehyde) were present in all samples. Five of the
34 aroma compounds detected by GC-MS (2,3-butanedione, methional, acetoin, octanal, 3-methylbutanal, and acetic acid) were present in all except 1 sour cream. All aroma-active compounds detected were derived through chemical conversion of the components present within the milk or heat treatment of the milk. The conversion of fat (lipolysis), lactose (glycolysis), and caseins (proteolysis) are the major metabolic pathways involved in the formation of aroma-active compounds in dairy products (Singh et al., 2003; Cadwallader and Singh, 2009). Previous research has identified all of these compounds in fermented dairy products, including buttermilk (Heiler and Schieberle, 1996), yogurt (Serra et al., 2009), goat cheese (Carunchia-Whetstine et al., 2003), Muenster cheese (Singh et al., 2003), and Cheddar cheese (Singh et al., 2003

Compounds such as EZ-2,6-nonadienal, EE-2,4nonadienal, methional, E-nonanal, 1-octene-3-one, nonanal, and 2-hexanol were identified at variable fat levels of sour cream (Tables 7 and 8). Previous research has demonstrated that some aldehydes and sulfur compounds contribute to cardboard flavor (Whitson et al., 2010) and potato and brothy flavors in dairy products (Carunchia Whetstine et al., 2005; Wright et al., 2006). 


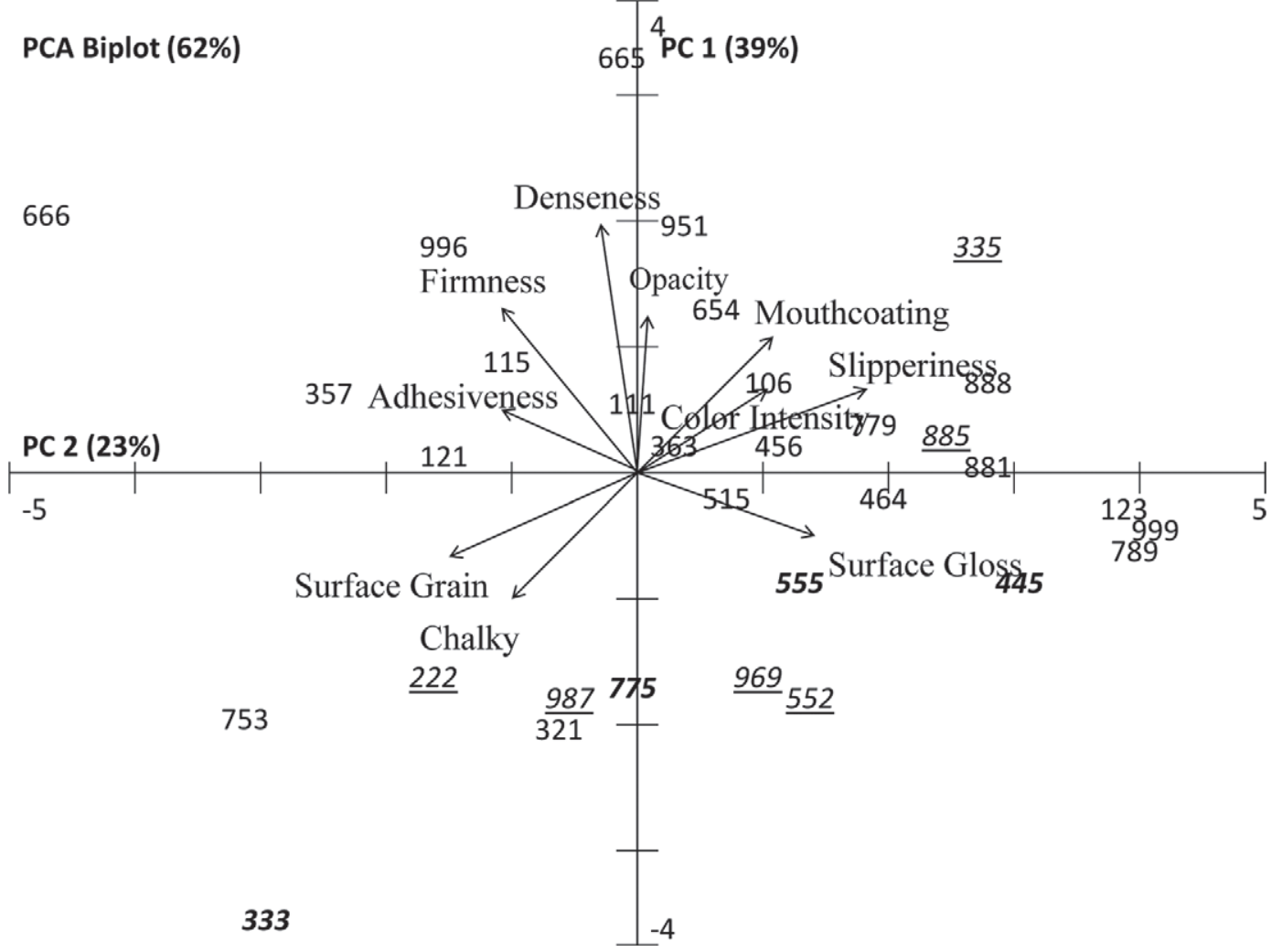

Figure 3. Principal components (PC) analysis (PCA) biplot (PC 1 and 2) of texture and visual appearance attributes of sour creams. Full-fat sour creams are numbers, reduced-fat sour creams are underlined and italic numbers, and fat-free sour creams are bold numbers.

Although varying fat levels of sour creams had these compounds present, the sensory profile for full-fat sour creams had collectively lower intensities of cardboard, potato, and brothy flavors present compared with reduced-fat and fat-free samples.

Fat content has a role in flavor release and its role is dependent on the aromatic compound being investigated (Cadwallader and Singh, 2009). Brauss et al. (1999) found that low-fat yogurts released volatiles more quickly and at higher concentrations than full-fat yogurts. This difference was demonstrated by higher sensory thresholds in oil compared with water (Relkin et al., 2004). The presence of fat also solubilizes hydrophobic flavor compounds and, therefore, only a small amount of hydrophobic flavor compounds are allowed into the headspace, thus increasing the sensory threshold. Flavor molecules in low-fat foods are not as soluble and have lower thresholds than full-fat products, which allows for higher flavor release (Kim et al., 2011). This may also explain why cardboard, potato, and brothy flavors were more prevalent in reduced-fat and fat-free sour creams compared with full-fat products.

Aroma-active compounds 2,3-butanedione and acetoin were present in 31 of 32 sour creams evaluated. However, higher amounts of acetoin were detected than 2,3-butanedione. The presence of these compounds corresponds with previous literature, in that 2,3-butanedione is produced by lactic acid bacteria in lower quantities than acetoin (Cadwallader and Singh, 2009). These compounds are produced by metabolism of citrate, which is present at low levels in bovine milk, by lactic acid bacteria (Cadwallader and Singh, 2009). Acetaldehyde is an aroma-active volatile that is prevalent in sour cream and yogurt (Cadwallader and Singh, 2009). Acetaldehyde is produced by lactic acid bacteria (Cadwallader and Singh, 2009) and is formed from an intermediate (pyruvate) by glycolysis (Smit et al., 2005). Acetaldehyde plays a role in the sour aromatic flavor present in sour cream, so as expected, the sour cream with the highest amount of acetaldehyde had the highest intensity of sour aromatic flavor (Tables 7 and 8).

Correlation analysis confirmed relationships between flavor-active compounds and sensory flavor attributes. Acetaldehyde was correlated with green/acetaldehyde, sour taste, and sour aromatic flavor $(\mathrm{r}=0.62,0.58$, and 0.61 , respectively; $P<0.05$ ). The flavor-active compound methional was correlated with potato flavor $(\mathrm{r}=0.85 ; P<0.05)$. Previous research demonstrated that cardboard flavor was due to the presence of alde- 
Table 4. Organic acid concentrations $(\mathrm{mg} / \mathrm{kg}$, unless otherwise indicated) of commercial sour creams $(\mathrm{n}=$ $32)^{1,2}$

\begin{tabular}{|c|c|c|c|c|c|c|c|c|}
\hline Item & Citric & $\begin{array}{c}\text { Lactic, } \\
\mathrm{g} / \mathrm{kg}\end{array}$ & Formic & Uric $^{3}$ & Orotic $^{4}$ & Pyruvic & Butyric & Acetic \\
\hline \multicolumn{9}{|c|}{ Sample } \\
\hline \multicolumn{9}{|c|}{ Full fat } \\
\hline 106 & 26.5 & 2.09 & 46.0 & 4.00 & 9.00 & 10.0 & 43.0 & 145 \\
\hline 779 & 76.3 & 2.44 & 57.6 & 5.42 & 10.9 & 5.82 & 127 & 174 \\
\hline 121 & 16.8 & 2.47 & 48.2 & 4.42 & 16.4 & 1.99 & 41.6 & 177 \\
\hline 111 & 16.8 & 2.02 & 48.2 & 3.97 & 9.91 & 2.12 & 115 & 148 \\
\hline 515 & 212 & 2.52 & 56.6 & 5.74 & 10.7 & 7.11 & 116 & 168 \\
\hline 115 & 31.8 & 2.93 & 61.2 & 5.08 & 11.9 & 2.11 & 144 & 220 \\
\hline 464 & 167 & 2.16 & 50.6 & 3.80 & 40.5 & 7.35 & 50.8 & 253 \\
\hline 881 & 19.7 & 2.26 & 47.6 & 5.09 & 9.57 & 3.76 & 105 & 178 \\
\hline 363 & 23.0 & 2.29 & 46.2 & 4.78 & 10.2 & 2.58 & $\mathrm{ND}^{5}$ & 164 \\
\hline 357 & 86.7 & 4.32 & 38.6 & 6.55 & 4.30 & 9.47 & 810 & ND \\
\hline 321 & 26.2 & 2.10 & 55.0 & 4.30 & 7.74 & 4.68 & 106 & 169 \\
\hline 654 & 146 & 2.39 & 63.0 & 5.53 & 6.94 & 6.83 & ND & 134 \\
\hline 123 & 20.4 & 2.14 & 54.5 & 3.95 & 8.00 & 4.80 & 63.1 & 114 \\
\hline 888 & 22.5 & 2.55 & 58.1 & 4.27 & 9.67 & 5.65 & 73.0 & 231 \\
\hline 999 & 11.2 & 1.84 & 57.7 & 4.15 & 7.30 & 3.68 & ND & 153 \\
\hline 456 & 37.6 & 2.20 & 47.1 & 4.00 & 9.81 & 3.61 & 50.8 & 147 \\
\hline 951 & 22.7 & 1.52 & 76.8 & 0.57 & 8.45 & ND & 59.6 & 110 \\
\hline 996 & 22.2 & 2.14 & 56.4 & 4.08 & 8.35 & 5.79 & 131 & 189 \\
\hline 666 & 15.1 & 2.60 & 48.0 & 5.15 & 10.1 & 9.14 & ND & 174 \\
\hline 665 & 24.7 & 2.89 & 73.2 & 5.17 & 11.6 & 3.40 & 432 & 187 \\
\hline 789 & 43.3 & 2.12 & 50.1 & 3.67 & 7.11 & 3.50 & 90.9 & 120 \\
\hline 753 & 10.6 & 2.67 & 62.4 & 4.86 & 11.0 & 3.96 & 121 & 241 \\
\hline \multicolumn{9}{|c|}{ Reduced fat } \\
\hline 222 & 44.0 & 3.55 & 89.6 & 6.31 & 12.4 & 6.07 & 114 & 224 \\
\hline 335 & 43.6 & 2.37 & 60.2 & 4.13 & 7.69 & 4.78 & 121 & 159 \\
\hline \multicolumn{9}{|l|}{ Light } \\
\hline 969 & 23.8 & 2.70 & 59.8 & 4.77 & 8.50 & 2.02 & 109 & 168 \\
\hline 552 & 815 & 3.36 & 190 & 6.26 & 13.1 & 4.59 & 167 & 232 \\
\hline 987 & 186 & 2.46 & 83.6 & 5.10 & 10.2 & 3.29 & 81.3 & 167 \\
\hline 885 & 24.3 & 2.91 & 67.2 & 7.86 & 17.0 & ND & 97.5 & 39.8 \\
\hline \multicolumn{9}{|c|}{ Fat free } \\
\hline 445 & 58.0 & 2.78 & 69.5 & 5.65 & 12.1 & 3.49 & 94.7 & 201 \\
\hline 333 & 21.4 & 2.39 & 16.8 & 11.6 & 14.2 & 2.60 & ND & 66.2 \\
\hline 555 & 41.4 & 3.77 & 73.5 & 9.36 & 19.8 & 5.36 & 146 & 419 \\
\hline 775 & 364 & 3.82 & 89.5 & 7.95 & 12.9 & 9.70 & 119 & 320 \\
\hline LSD & 93.1 & 0.326 & 161 & 3.07 & 16.4 & 2.06 & 30.4 & 31.4 \\
\hline
\end{tabular}

${ }^{1}$ Organic acid concentration of commercial sour cream $(n=32)$ by HPLC peak absorbance. Measurements were taken at a wavelength of $220 \mathrm{~nm}$.

${ }^{2}$ Only a few sour creams contained hippuric and propionic acids. The sample that contained hippuric acid was $115(1 \mathrm{mg} / \mathrm{kg})$. The samples that contained propionic acid included $665(18 \mathrm{mg} / \mathrm{kg}), 888(24 \mathrm{mg} / \mathrm{kg}), 885(64$ $\mathrm{mg} / \mathrm{kg}), 666(76 \mathrm{mg} / \mathrm{kg})$, and $464(16 \mathrm{mg} / \mathrm{kg})$. The LSD value for propionic acid was 8.31 .

${ }^{3}$ Measurements taken at a wavelength of $290 \mathrm{~nm}$.

${ }^{4}$ Measurements taken at a wavelength of $275 \mathrm{~nm}$.

${ }^{5} \mathrm{ND}=$ not detected.

hydes and some sulfur-containing compounds (Whitson et al., 2010). The sensory attribute cardboard was correlated with flavor-active aldehyde compound E,E-2,4nonadienal and dimethyl trisulfide $(\mathrm{r}=0.81$ and 0.60 , respectively; $P<0.05)$. Butyric acid was correlated with FFA flavor $(\mathrm{r}=0.85 ; P<0.05)$. Diacetyl flavor was correlated with 2,3 -butanedione $(\mathrm{r}=0.59 ; P<0.05)$.

\section{Consumer Acceptance}

Consumers were asked to rank the importance of the factors that influenced their purchase of sour cream. Flavor was the top factor for sour cream users, followed by price, availability, and brand. Sour cream was most used as a topping, then as an ingredient, and then as a dip. Full-fat sour creams collectively received higher liking scores than reduced-fat and fat-free sour creams from consumers (Table 9). Sour cream 357, a full-fat product, was considered to be too sour by the majority of consumers $(78 \%)$, whereas reduced-fat samples were generally penalized for not being smooth enough $(P<$ 0.05; Table 9). Therefore, these sour creams (357 and reduced-fat sour creams) received the lowest overall liking scores.

Consumer segmentation was used to investigate specific consumer preferences and drivers of liking for sour 


\begin{tabular}{|c|c|c|c|c|c|c|c|c|c|c|c|c|c|c|c|c|c|c|c|c|}
\hline \multirow[b]{2}{*}{ Aroma } & \multirow{2}{*}{$\begin{array}{l}\mathrm{RI}^{2} \\
\text { (ZB- } \\
5 \mathrm{~ms})\end{array}$} & \multirow{2}{*}{$\begin{array}{c}\mathrm{RI}^{3} \\
(\mathrm{ZB}- \\
\text { WAX) }\end{array}$} & \multirow[b]{2}{*}{ Compound } & \multicolumn{17}{|c|}{ Sample } \\
\hline & & & & $106^{4}$ & $111^{4}$ & $115^{4}$ & $121^{4}$ & $123^{4}$ & $222^{5}$ & $321^{4}$ & $333^{6}$ & $335^{5}$ & $357^{4}$ & $363^{4}$ & $445^{6}$ & $456^{4}$ & $464^{4}$ & $515^{4}$ & $552^{7}$ & $555^{6}$ \\
\hline Sulfur & $<600$ & 680 & Dimethyl sulfide & + & + & + & + & & + & + & & + & + & + & + & + & + & + & + & + \\
\hline Ether/solvent & $<600$ & $<600$ & 2-Butanone & + & + & & + & + & & + & + & & & + & & & & & & + \\
\hline Butter & $<600$ & 876 & 2,3-Butanedione & + & + & + & + & + & + & + & + & + & + & + & + & & + & + & + & + \\
\hline Acetic/vinegar & $<600$ & 1,335 & Acetic acid & + & + & + & + & + & & + & + & + & + & + & + & & + & + & + & + \\
\hline Malty/chocolate & 611 & 614 & 2 or 3 -Methyl butanal & + & & & + & & + & + & & & + & & & & + & + & + & + \\
\hline Garlic/cabbage & 615 & & Methyl ethyl sulfide & & & & & & & & & & & & & & & & & + \\
\hline Rubbery & 680 & & 1-Hexen-3-one & + & + & + & + & + & + & + & + & + & + & + & & & + & + & + & + \\
\hline Cheesy/FFA & 806 & 1,631 & Butyric acid & + & + & + & + & & + & & + & & & + & & & & & & + \\
\hline Grassy & 802 & 1,011 & Hexanal & + & & & & & + & & + & & + & & & & + & & & \\
\hline Fruity & 859 & 1,159 & Isopropyl butanoate & & & & & & & & & & & & & & & & & \\
\hline Cooked/brothy & 866 & 1,262 & 2-Methyl-3-furanthiol & + & + & + & + & & + & + & + & + & + & & + & + & + & + & + & + \\
\hline Green & 890 & & 2-Hexanol & + & + & & & & & & & & & & & & & & & \\
\hline Fishy/fatty & 899 & 1,146 & Z-4 Heptenal & & + & & & + & & & & & & & & + & + & & & + \\
\hline Potato & 905 & 1,395 & Methional & + & + & + & + & & + & + & + & + & + & + & + & + & + & & + & + \\
\hline Popcorn & 921 & 1,345 & 2-Acetyl pyrroline & & & & & & & & & & & & & & & & & \\
\hline Fruity & 924 & & Ethyl isohexanoate & & & & + & & & + & & & & & & & + & + & + & + \\
\hline Sulfur (cabbage, garlic) & 969 & & Dimethyl trisulfide & + & & & + & + & & & + & + & & & & & & + & + & + \\
\hline Mushroom & 976 & & 1-Octene-3-one & & & & + & & & & + & & & & & & & + & & + \\
\hline Green, metal & 987 & 1,205 & 2-Pentyl furan & + & + & & + & & + & & + & & & + & & & + & & + & \\
\hline Fruity & 996 & & Ethyl methyl pyrazine & + & & & & & & & & & & & & & & & & \\
\hline Citrus/fruity & 1,002 & 1,263 & Octanal & + & & & + & & + & & + & & + & & & & + & + & & + \\
\hline Fruit, cocoa & 1,051 & & Butyl methyl butyrate & & & & & & & & & & & & & & & & & \\
\hline $\begin{array}{l}\text { Sweet/caramelized } \\
\text { sugar }\end{array}$ & 1,064 & 1,416 & Furaneol & & & & & & & & + & & & & & & & & & \\
\hline Citrus/sweet & 1,075 & & Dimethylheptenal & + & & & & & & & & & & & & & & & & \\
\hline Sweet/smoky & 1,081 & 1,479 & Guaiacol & + & + & & & & + & & + & + & & & & & + & & + & + \\
\hline Sweet fatty cucumbers & 1,100 & 1,331 & Nonanal & + & & & + & + & + & + & + & + & & + & + & & + & & + & + \\
\hline Popcorn & 1,107 & 1,757 & 2-Acetyl-2-thiazoline & + & & & & & + & + & & & & & & & & & + & + \\
\hline Maple/curry & 1,129 & & Sotolone & + & & & & & & & + & & & & & & & & & + \\
\hline Green, cucumbers & 1,151 & 1,530 & E,Z,-2,6-Nonadienal & + & & & & & & & + & + & + & & & & + & & + & \\
\hline Carpet & 1,166 & 1,493 & E-2-nonenal & + & + & & + & & & + & & + & + & + & + & & & + & + & \\
\hline Licorice & 1,173 & & Estragole & & & & & & & & & & & & & + & & & & + \\
\hline Pasta/fatty & 1,175 & 1,687 & $\begin{array}{l}\text { Methyl-2-methyl-3-furyl } \\
\text { disulfide }\end{array}$ & & & & & + & & & & & & & & & & & & \\
\hline Bell pepper & 1,182 & & $\begin{array}{l}\text { 2-Isobutyl-3- } \\
\text { methoxypyrazine }\end{array}$ & & & & & & & & & & & & & & & & & + \\
\hline Fatty hay & 1,221 & 1,677 & E,E-2,4-Nonadienal & & & & & & & & + & & & & & & & & & + \\
\hline Minty hay & 1,220 & & 2-Octyl-furan & & & & & & & & + & & & & & & & & & + \\
\hline Stale/grapy/tortilla & 1,333 & & $o$-Aminoacetophenone & + & & & & & & & + & & & & & & & & & \\
\hline Phenolic rubbery & 1,347 & & Benzolthiazole & & & & & & & & & & & & & & & & & + \\
\hline Sweet/peach & 1,448 & & $\gamma$-Decalactone & & & & & & & & & & & & & & & & & \\
\hline Coconut/soapy & 1,503 & & $\delta$-Decalactone & & & & & & & & & & & & & & + & & & \\
\hline Popcorn & 1,107 & 1,757 & 2-Acetyl-2-thiazoline & + & & & & & & & & & & & & & & & + & + \\
\hline
\end{tabular}

+ indicates the presence of compound detected by 2 experienced sniffers; blank indicates the absence of the compound.

${ }^{2}$ Retention indices (RI) of the aroma event on the ZB-5ms column (Zebron; Phenomenex Inc., Torrance, CA).

${ }^{3}$ Retention indices on the ZB-WAX column (Zebron; Phenomenex Inc.).

${ }^{4}$ Full-fat sour cream.

${ }^{5}$ Reduced-fat sour cream.

${ }^{6}$ Fat-free sour cream.

${ }^{7}$ Light sour cream. 
Table 6. Aroma-active compounds in sour creams ${ }^{1}$

\begin{tabular}{|c|c|c|c|c|c|c|c|c|c|c|c|c|c|c|c|c|c|c|}
\hline \multirow[b]{2}{*}{ Aroma } & \multirow{2}{*}{$\begin{array}{c}\mathrm{RI}^{2} \\
\text { (ZB- } \\
5 \mathrm{~ms})\end{array}$} & \multirow{2}{*}{$\begin{array}{c}\mathrm{RI}^{3} \\
(\mathrm{ZB}- \\
\text { WAX) }\end{array}$} & \multirow[b]{2}{*}{ Compound } & \multicolumn{15}{|c|}{ Sample } \\
\hline & & & & $654^{4}$ & $665^{4}$ & $666^{4}$ & $753^{4}$ & $775^{5}$ & $779^{4}$ & $789^{4}$ & $881^{4}$ & $885^{6}$ & $888^{4}$ & $951^{4}$ & $969^{6}$ & $987^{6}$ & $996^{4}$ & $999^{4}$ \\
\hline $\begin{array}{l}\text { Sulfur } \\
\text { Ether/solvent }\end{array}$ & $\begin{array}{l}<600 \\
<600\end{array}$ & $\begin{array}{r}680 \\
<600\end{array}$ & Dimethyl sulfide & + & + & + & + & + & + & + & + & + & + & + & + & $\begin{array}{l}+ \\
+\end{array}$ & $\begin{array}{l}+ \\
+\end{array}$ & + \\
\hline $\begin{array}{l}\text { Ether/solvent } \\
\text { Butter }\end{array}$ & $\begin{array}{l}<600 \\
<600\end{array}$ & $\begin{array}{r}<000 \\
876\end{array}$ & $\begin{array}{l}\text { 2-Butanone } \\
2.3 \text {-Butanedione }\end{array}$ & + & + & + & + & + & + & + & + & + & + & + & + & $\begin{array}{l}+ \\
+\end{array}$ & $\begin{array}{l}+ \\
+\end{array}$ & + \\
\hline Acetic/vinegar & $<600$ & 1,335 & Acetic acid & & + & + & & + & + & + & + & + & + & + & + & & + & + \\
\hline Malty/chocolate & 611 & 614 & 2 or 3 -Methyl butanal & + & + & + & & + & + & + & + & + & & & + & & + & \\
\hline Garlic/cabbage & 615 & & Methyl ethyl sulfide & & & & & + & & & & & & & & & & \\
\hline Rubbery & 680 & & 1-Hexen-3-one & + & + & + & + & & & & + & + & + & & + & & + & + \\
\hline Cheesy/FFA & 806 & 1,631 & Butyric acid & + & + & & & + & + & + & & & + & & & + & & + \\
\hline Grassy & 802 & 1,011 & Hexanal & & & & & & & + & & & & & & & & \\
\hline Fruity & 859 & 1,159 & Isopropyl butanoate & & & & & & & + & & & & & & & & \\
\hline Cooked/brothy & 866 & 1,262 & 2-Methyl-3-furanthiol & + & + & + & + & + & + & + & + & + & + & & + & + & + & + \\
\hline Green & 890 & & 2-Hexanol & & & & & + & & & & & & & & & & \\
\hline Fishy/fatty & 899 & 1,146 & Z-4 Heptenal & + & & + & & + & & & & + & & + & & + & & \\
\hline Potato & 905 & 1,395 & Methional & + & + & + & + & + & + & + & + & + & + & + & + & + & + & + \\
\hline Popcorn & 921 & 1,345 & 2-Acetyl pyrroline & + & & + & & & & & & & + & & & + & & \\
\hline Fruity & 924 & & Ethyl isohexanoate & & & & & & & & & & & & & & & \\
\hline Sulfur (cabbage, garlic) & 969 & & Dimethyl trisulfide & & + & & & + & + & + & + & + & + & & + & + & + & + \\
\hline Mushroom & 976 & & 1-Octene-3-one & & & & & & + & & & + & & & & + & & + \\
\hline Green, metal & 987 & 1,205 & 2-Pentyl furan & & + & & + & & & + & & + & & + & + & + & + & \\
\hline Fruity & 996 & & Ethyl methyl pyrazine & & & & & & + & & & & & & & & & + \\
\hline Citrus/fruity & 1,002 & 1,263 & Octanal & & + & & & + & + & & & + & + & + & + & + & & + \\
\hline Fruit, cocoa & 1,051 & & Butyl methyl butyrate & & + & & & + & & & & & & & & & & \\
\hline Sweet/caramelized sugar & 1,064 & 1,416 & Furaneol & & & + & & & & & & & & & & & & \\
\hline Citrus/sweet & 1,075 & & Dimethylheptenal & & & & & & & & & & & & & & + & \\
\hline Sweet/smoky & 1,081 & 1,479 & Guaiacol & + & + & + & & + & & + & + & + & + & & + & & & + \\
\hline Sweet fatty cucumbers & 1,100 & 1,331 & Nonanal & + & & + & & + & + & + & & + & & + & + & + & & + \\
\hline Popcorn & 1,110 & 1,757 & 2-Acetyl-2-thiazoline & & & & & & & & & & & & + & & & \\
\hline Maple/curry & 1,129 & & Sotolone & & & & & & & & & & & + & & & & \\
\hline Green, cucumbers & 1,151 & 1,530 & E,Z,-2,6-Nonadienal & & & & + & & & + & & + & & & & + & & + \\
\hline Carpet & 1,166 & 1,493 & E-2-Nonenal & + & + & + & & & + & + & & + & + & & + & & & \\
\hline Licorice & 1,173 & & Estragole & & & & & & & & & & + & & & & & \\
\hline Pasta/fatty & 1,175 & 1,687 & $\begin{array}{l}\text { Methyl-2-methyl-3-furyl } \\
\text { disulfide }\end{array}$ & & & & & + & & & + & & & & & & & \\
\hline Bell pepper & 1,182 & & $\begin{array}{l}\text { 2-Isobutyl-3- } \\
\text { methoxypyrazine }\end{array}$ & & & & & & & & & & & & & & & \\
\hline Fatty hay & 1,221 & 1,677 & E,E-2,4-Nonadienal & + & & & + & & & & & & & & & & & \\
\hline Minty hay & 1,220 & & 2-Octyl-furan & & & & & & & & & & & & & & & \\
\hline Stale/grapy/tortilla & 1,333 & & o-Aminoacetophenone & & & & & & & & & & & & & & & \\
\hline Phenolic rubbery & 1,347 & & Benzolthiazole & + & & & & & & & & & & & & & & \\
\hline Sweet/peach & 1,448 & & $\gamma$-Decalactone & & & & & & & & & & & & & & & \\
\hline Coconut/soapy & 1,503 & & $\delta$-Decalactone & & & & & & & & & & & & & & & \\
\hline Popcorn & 1,107 & 1,757 & 2-Acetyl-2-thiazoline & & & & & & & & & & & & + & & & \\
\hline \multicolumn{19}{|c|}{$\begin{array}{l}{ }^{1}+\text { indicates the presence of compound detected by } 2 \text { experienced sniffers; blank indicates the absence of the compound. } \\
\text {. }\end{array}$} \\
\hline \multirow{5}{*}{\multicolumn{19}{|c|}{$\begin{array}{l}{ }^{2} \text { Retention indices (RI) of the aroma event on the ZB-5ms column (Zebron; Phenomenex Inc., Torrance, CA). } \\
{ }^{3} \text { Retention indices on the ZB-WAX column (Zebron; Phenomenex Inc.). } \\
{ }^{4} \text { Full-fat sour cream. }\end{array}$}} \\
\hline & & & & & & & & & & & & & & & & & & \\
\hline & & & & & & & & & & & & & & & & & & \\
\hline & & & & & & & & & & & & & & & & & & \\
\hline & & & & & & & & & & & & & & & & & & \\
\hline
\end{tabular}


Table 7. Relative abundance of selected aroma-active compounds in sour cream $(\mu \mathrm{g} / \mathrm{kg})$

Sample

\begin{tabular}{|c|c|c|c|c|c|c|c|c|c|c|c|c|c|c|c|c|}
\hline Compound & $111^{2}$ & $115^{2}$ & $121^{2}$ & $123^{2}$ & $321^{2}$ & $779^{2}$ & $789^{2}$ & $357^{2}$ & $363^{2}$ & $456^{2}$ & $464^{2}$ & $515^{2}$ & $999^{2}$ & $106^{2}$ & $654^{2}$ & $\mathrm{LSD}^{1}$ \\
\hline 2-Pentyl furan & 2.8 & 0.7 & 3.3 & 6.0 & 4.1 & 3.1 & 8.3 & 2.5 & 1.7 & $\mathrm{ND}^{3}$ & 0.7 & 1.6 & 1.0 & 3.8 & ND & 2.2 \\
\hline E,E-2,4-Nonadienal & ND & ND & 0.1 & ND & ND & ND & 0.1 & ND & ND & ND & ND & ND & ND & $\mathrm{ND}$ & ND & 0.24 \\
\hline Acetaldehyde & 633.3 & 116.9 & 330.5 & 79.4 & 180.3 & 56.6 & 129.3 & 887.6 & 93.6 & 61.7 & 28.7 & 43.7 & 65.4 & 143.1 & 147.3 & 47 \\
\hline$o$-Cresol & ND & 0.8 & 1.5 & 0.6 & ND & ND & 2.3 & ND & ND & ND & 0.1 & ND & ND & ND & ND & 2.3 \\
\hline Dimethyl heptenal & ND & ND & 3.7 & 10 & ND & ND & 8.8 & ND & ND & ND & ND & ND & ND & 0.2 & ND & 0.4 \\
\hline 2-Ethyl-5-methyl pyrazine & ND & ND & ND & ND & ND & ND & ND & ND & ND & ND & ND & ND & ND & ND & ND & ND \\
\hline Sotolone & 0.6 & 26.3 & 1.2 & 0.8 & 0.7 & 0.5 & 2.0 & ND & ND & ND & 82.5 & ND & ND & 10.9 & 117.9 & 32 \\
\hline Butyl-2-methylbutyrate & 2.9 & 1.8 & 4.5 & 1.9 & ND & 1.6 & 4.2 & ND & ND & ND & 2.7 & 1.0 & 1.7 & 3.3 & 3.8 & 2.3 \\
\hline Isopropyl butanoate & 0.9 & 1.3 & 2.4 & 0.5 & ND & 0.7 & 4.3 & ND & ND & ND & 1.1 & 2.4 & 1.5 & 6.7 & ND & 1.8 \\
\hline$\gamma$-Decalactone & ND & ND & ND & ND & ND & ND & ND & 1.3 & ND & ND & ND & ND & ND & ND & ND & 0.4 \\
\hline 2,3-Butanedione & 14.8 & 5.1 & 31.5 & 24.2 & 1.5 & 30.7 & 59.0 & 1.8 & 34.3 & ND & 13.9 & 4.6 & 0.45 & 128.5 & 4.2 & 16 \\
\hline Acetoin & 40.4 & 0.2 & 240 & 513 & 4.1 & 40.7 & 409.6 & 27.5 & 10.4 & ND & 0.2 & 2.6 & 1.5 & 290.0 & 10.9 & 1.1 \\
\hline Ethyl isohexanoate & 1.5 & 1.1 & 0.8 & 0.5 & 1.5 & 1.7 & 0.8 & ND & 1.2 & ND & ND & ND & ND & 0.4 & ND & 1.1 \\
\hline$\delta$-Decalactone & 3.0 & 2.0 & 0.8 & 0.1 & 2.0 & 1.0 & 1.1 & 4.3 & 1.4 & 1.2 & 0.4 & 0.2 & 0.3 & 0.7 & 2.4 & 1.0 \\
\hline Methional & 1.9 & 3.9 & 1.0 & 1.1 & 0.8 & 5.3 & 1.2 & 7.0 & 3.6 & 2.8 & 3.0 & 0.6 & 1.2 & 3.6 & 4.4 & 1.0 \\
\hline Guaiacol & ND & ND & 0.2 & 0.1 & 0.7 & 0.3 & 0.4 & 0.2 & ND & ND & ND & ND & ND & 0.2 & ND & 1.0 \\
\hline 2-Methyl-3-furanthiol & 2.5 & 0.6 & 0.7 & 2.9 & 4.6 & 12.8 & 9.2 & 3.1 & 2.3 & 2.5 & 0.5 & 0.3 & 1.3 & 4.1 & 1.1 & 1.4 \\
\hline Dimethyl trisulfide & 0.1 & 0.3 & 1.0 & 0.8 & 2.3 & 0.5 & 1.2 & 0.9 & 0.4 & 0.4 & 0.3 & 0.1 & 0.2 & 0.8 & 0.4 & 1.3 \\
\hline 1-Hexen-3-one & 2.6 & 1.5 & 4.0 & 3.8 & 1.6 & 0.8 & 13.7 & 16.7 & 1.7 & 0.6 & 5.6 & 2.6 & 0.8 & 6.4 & 4.0 & 1.5 \\
\hline E-2-Nonenal & 15.4 & 4.2 & 0.6 & ND & 20 & 4.5 & 1.1 & 106 & 0.3 & ND & 6.3 & ND & 0.3 & 1.6 & 9.6 & 1.5 \\
\hline Hexanal & 9.2 & 1.3 & 41.2 & 126.1 & ND & 3.6 & 68.3 & 6.5 & ND & ND & 2.5 & 0.8 & 1.9 & 76.7 & ND & 6.5 \\
\hline Octanal & 17.5 & 20 & 106 & 11.3 & 944.5 & 8.9 & 15.2 & ND & 6.2 & 2.5 & 20.5 & 7.9 & 14.2 & 8.8 & 7.9 & 7.5 \\
\hline 2-Hexanol & 0.4 & ND & 1.3 & 0.6 & ND & 2.7 & 4.3 & ND & ND & ND & 13.5 & 0.7 & 0.6 & 4.4 & ND & 1.0 \\
\hline Nonanal & 4.7 & 1.8 & 11.7 & 5.7 & 8.9 & 6.2 & 16.3 & 107 & 1.5 & 1.1 & 11.2 & 10 & 1.1 & 8.6 & 13.6 & 1.0 \\
\hline 3-Methyl butanal & 38.0 & 9.4 & 0.2 & 0.5 & 28.2 & 24.5 & ND & 62.2 & ND & 0.8 & ND & 0.7 & 3.8 & 17.2 & 3.3 & 1.6 \\
\hline Acetic acid & 822.7 & 652.3 & 1,026 & ND & 986.1 & 619.6 & 1.74 & 1,289 & 542.2 & ND & ND & ND & 503.3 & 1,139 & ND & 8.1 \\
\hline Butyric acid & 144.6 & 63.2 & 47.7 & 120.3 & 333.1 & 56.4 & 97.6 & 214.3 & 188.3 & 2.35 & 1.83 & 9.03 & 54.7 & 79.3 & 4.03 & 6.3 \\
\hline 2-Acetyl-2-thiazoline & 0.6 & 2.8 & ND & ND & ND & 0.4 & 0.2 & ND & ND & ND & 14.9 & ND & ND & 0.4 & ND & 2.0 \\
\hline Dimethyl sulfide & 2.5 & 2.2 & 3.8 & 3.1 & 3.9 & 2.3 & 2.8 & 5.9 & 3.3 & 1.7 & 0.9 & 1.7 & 3.0 & 2.8 & 1.1 & 0.78 \\
\hline Z-4-Heptenal & 2.5 & ND & 2.9 & 5.6 & ND & 0.5 & 9.2 & 7.7 & 1.2 & 2.0 & 9.9 & 2.0 & 3.0 & 4.2 & 26.3 & 2.2 \\
\hline 1-Octene-3-one & 34.9 & 5.6 & 2.5 & 2.3 & 21.4 & 12.8 & 10 & 9.9 & 9.1 & 0.2 & 3.4 & 0.6 & 4.4 & 6.1 & 7.6 & 5.0 \\
\hline E,Z-2,6-Nonadienal & 0.1 & 0.7 & 0.3 & ND & ND & ND & 0.5 & ND & ND & ND & ND & ND & ND & 0.2 & ND & 0.57 \\
\hline 2-Butanone & 12.6 & 4.8 & 46.2 & 17.0 & 9.8 & 8.0 & 26.6 & ND & 4.6 & ND & 13.2 & 10.3 & 5.7 & 31.1 & ND & 6.5 \\
\hline
\end{tabular}

${ }^{1}$ Means within a row that differ by LSD are different $(P<0.05)$.

${ }^{2}$ Full-fat sour cream.

${ }^{3} \mathrm{ND}=$ not detected 
Table 8. Relative abundance of selected aroma-active compounds in sour cream $(\mu \mathrm{g} / \mathrm{kg})$

Sample

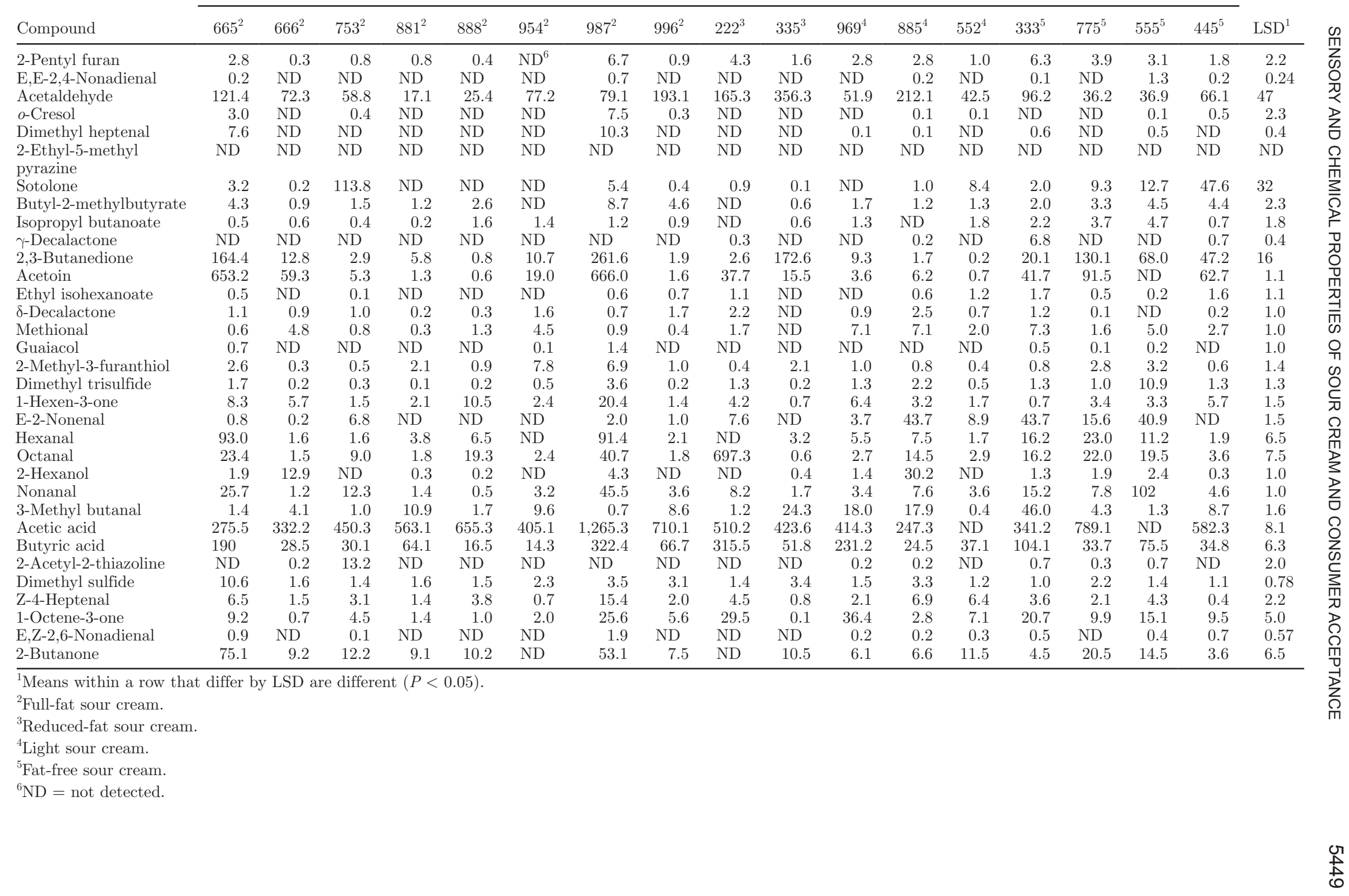


Table 9. Overall liking attribute means from consumer acceptance testing of sour cream ${ }^{1}$

\begin{tabular}{|c|c|c|c|c|c|c|c|c|c|c|c|c|}
\hline \multirow[b]{2}{*}{ Item $^{2}$} & \multicolumn{12}{|c|}{ Sample } \\
\hline & $996^{3}$ & $222^{4}$ & $111^{3}$ & $969^{5}$ & $106^{3}$ & $115^{3}$ & $363^{3}$ & $357^{3}$ & $885^{5}$ & $888^{3}$ & $789^{3}$ & $753^{3}$ \\
\hline Appearance & $6.9^{\mathrm{a}}$ & $5.5^{\mathrm{c}}$ & $7.1^{\mathrm{a}}$ & $5.8^{\mathrm{c}}$ & $7.2^{\mathrm{a}}$ & $6.3^{\mathrm{b}}$ & $7.2^{\mathrm{a}}$ & $7.1^{\mathrm{a}}$ & $4.9^{\mathrm{d}}$ & $7.2^{\mathrm{a}}$ & $6.5^{\mathrm{b}}$ & $7.1^{\mathrm{a}}$ \\
\hline Color & $7.3^{\mathrm{bc}}$ & $6.6^{\mathrm{e}}$ & $7.5^{\mathrm{ab}}$ & $7.1^{\mathrm{d}}$ & $7.5^{\mathrm{ab}}$ & $7.1^{\mathrm{cd}}$ & $7.5^{\mathrm{ab}}$ & $7.4^{\mathrm{ab}}$ & $6.0^{\mathrm{f}}$ & $7.6^{\mathrm{a}}$ & $7.1^{\mathrm{d}}$ & $7.5^{\mathrm{ab}}$ \\
\hline Overall impression & $6.4^{\mathrm{bc}}$ & $4.6^{\mathrm{e}}$ & $5.5^{\mathrm{d}}$ & $5.27^{\mathrm{d}}$ & $6.57^{\mathrm{ab}}$ & $5.33^{\mathrm{d}}$ & $6.79^{\mathrm{a}}$ & $4.22^{\mathrm{e}}$ & $4.33^{\mathrm{e}}$ & $6.65^{\mathrm{ab}}$ & $6.18^{\mathrm{c}}$ & $5.39^{\mathrm{d}}$ \\
\hline Flavor & $6.3^{\mathrm{ab}}$ & $4.5^{\mathrm{d}}$ & $5.3^{\mathrm{c}}$ & $5.39^{\mathrm{c}}$ & $6.54^{\mathrm{a}}$ & $5.33^{\mathrm{c}}$ & $6.62^{\mathrm{a}}$ & $3.81^{\mathrm{e}}$ & $4.34^{\mathrm{d}}$ & $6.50^{\mathrm{a}}$ & $6.08^{\mathrm{b}}$ & $5.04^{\mathrm{c}}$ \\
\hline Fresh & $7.0^{\mathrm{ab}}$ & $5.8^{\mathrm{f}}$ & $6.6^{\mathrm{cd}}$ & $6.49^{\mathrm{de}}$ & $7.26^{\mathrm{a}}$ & $6.53^{\mathrm{de}}$ & $7.11^{\mathrm{ab}}$ & $5.93^{\mathrm{f}}$ & $5.79^{\mathrm{f}}$ & $7.20^{\mathrm{ab}}$ & $6.91^{\mathrm{bc}}$ & $6.28^{\mathrm{e}}$ \\
\hline Sourness & $6.0^{\mathrm{ab}}$ & $4.4^{\mathrm{d}}$ & $5.2^{\mathrm{c}}$ & $5.29^{\mathrm{c}}$ & $6.24^{\mathrm{a}}$ & $5.11^{\mathrm{c}}$ & $6.07^{\mathrm{ab}}$ & $3.58^{\mathrm{e}}$ & $4.32^{\mathrm{d}}$ & $6.10^{\mathrm{ab}}$ & $5.79^{\mathrm{b}}$ & $4.95^{\mathrm{c}}$ \\
\hline Texture & $6.4^{\mathrm{c}}$ & $5.4^{\mathrm{de}}$ & $6.7^{\mathrm{bc}}$ & $5.27^{\mathrm{e}}$ & $6.92^{\mathrm{ab}}$ & $5.68^{\mathrm{d}}$ & $7.12^{\mathrm{a}}$ & $5.59^{\mathrm{de}}$ & $4.66^{\mathrm{f}}$ & $7.21^{\mathrm{a}}$ & $6.44^{\mathrm{c}}$ & $6.62^{\mathrm{bc}}$ \\
\hline \multirow[t]{2}{*}{ Thickness } & $6.1^{\mathrm{c}}$ & $5.3^{\mathrm{e}}$ & $6.79^{\mathrm{ab}}$ & $5.72^{\mathrm{d}}$ & $6.77^{\mathrm{ab}}$ & $5.83^{\mathrm{cd}}$ & $6.99^{\mathrm{a}}$ & $4.87^{\mathrm{f}}$ & $4.19^{\mathrm{g}}$ & $7.04^{\mathrm{a}}$ & $6.13^{\mathrm{c}}$ & $6.54^{\mathrm{b}}$ \\
\hline & $31.3^{\mathrm{a}}$ & $7.46^{\mathrm{de}}$ & $20.9^{\mathrm{abc}}$ & $10.9^{\mathrm{cd}}$ & $15.4^{\mathrm{bc}}$ & $18.3^{\mathrm{bc}}$ & $4.97^{\mathrm{e}}$ & $3.97^{\mathrm{e}}$ & $25.9^{\mathrm{ab}}$ & $19.3^{\mathrm{abc}}$ & $14.9^{\mathrm{c}}$ & $31.3^{\mathrm{a}}$ \\
\hline \multirow{3}{*}{ Sour JAR, \% } & $48.7^{\mathrm{bc}}$ & $28.3^{\mathrm{d}}$ & $42.2^{\mathrm{bc}}$ & $46.7^{\mathrm{bc}}$ & $61.6^{\mathrm{a}}$ & $35.3^{\mathrm{cd}}$ & $56.7^{\mathrm{ab}}$ & $17.9^{\mathrm{e}}$ & $29.8^{\mathrm{d}}$ & $54.2^{\mathrm{ab}}$ & $52.2^{\mathrm{ab}}$ & $26.8^{\mathrm{d}}$ \\
\hline & $19.9^{\mathrm{e}}$ & $64.2^{\mathrm{b}}$ & $36.8^{\mathrm{d}}$ & $42.3^{\mathrm{c}}$ & $22.9^{\mathrm{e}}$ & $46.3^{\mathrm{c}}$ & $38.3^{\mathrm{d}}$ & $78.1^{\mathrm{a}}$ & $44.3^{\mathrm{c}}$ & $26.4^{\mathrm{e}}$ & $32.9^{\mathrm{d}}$ & $41.8^{\mathrm{c}}$ \\
\hline & $1.5^{\mathrm{e}}$ & $45.8^{\mathrm{b}}$ & $10.4^{\mathrm{cd}}$ & $17.4^{\mathrm{c}}$ & $3.5^{\mathrm{e}}$ & $18.4^{\mathrm{c}}$ & $3.5^{\mathrm{e}}$ & $1.5^{\mathrm{e}}$ & $73.6^{\mathrm{a}}$ & $12.4^{\text {cd }}$ & $36.8^{\mathrm{b}}$ & $12.0^{\mathrm{cd}}$ \\
\hline \multirow[t]{3}{*}{ Texture JAR, \% } & $57.7^{\mathrm{cd}}$ & $46.3^{\text {de }}$ & $81.6^{\mathrm{a}}$ & $51.7^{\mathrm{cd}}$ & $64.7^{\mathrm{bc}}$ & $58.7^{\mathrm{cd}}$ & $78.1^{\mathrm{a}}$ & $34.3^{\mathrm{ef}}$ & $24.4^{\mathrm{f}}$ & $82.1^{\mathrm{a}}$ & $58.2^{\mathrm{cd}}$ & $73.1^{\mathrm{a}}$ \\
\hline & $40.8^{\mathrm{b}}$ & $8.00^{\mathrm{f}}$ & $8.00^{\mathrm{f}}$ & $30.8^{\mathrm{bc}}$ & $31.8^{\mathrm{bc}}$ & $22.9^{\text {cd }}$ & $18.4^{\mathrm{de}}$ & $64.2^{\mathrm{a}}$ & $2.00^{\mathrm{fg}}$ & $5.50^{\mathrm{f}}$ & $5.00^{\mathrm{f}}$ & $14.9^{\mathrm{e}}$ \\
\hline & $16.4^{\mathrm{c}}$ & $31.8^{\mathrm{b}}$ & $12.0^{\mathrm{cd}}$ & $43.3^{\mathrm{a}}$ & $12.9^{\mathrm{cd}}$ & $27.9^{\mathrm{b}}$ & $8.50^{\mathrm{d}}$ & $28.3^{\mathrm{b}}$ & $41.8^{\mathrm{a}}$ & $6.50^{\mathrm{d}}$ & $18.4^{\mathrm{c}}$ & $14.4^{\mathrm{cd}}$ \\
\hline \multirow{3}{*}{ Smooth JAR, \% } & $72.6^{\mathrm{ab}}$ & $56.2^{\text {de }}$ & $80.1^{\mathrm{a}}$ & $45.3^{\mathrm{f}}$ & $76.1^{\mathrm{ab}}$ & $59.6^{\mathrm{cd}}$ & $83.6^{\mathrm{a}}$ & $54.7^{\mathrm{de}}$ & $36.8^{\mathrm{g}}$ & $81.1^{\mathrm{a}}$ & $69.6^{\mathrm{bc}}$ & $74.1^{\mathrm{ab}}$ \\
\hline & $11.0^{\mathrm{b}}$ & $11.9^{\mathrm{b}}$ & $7.95^{\mathrm{bc}}$ & $11.4^{\mathrm{b}}$ & $10.9^{\mathrm{b}}$ & $12.5^{\mathrm{b}}$ & $7.94^{\mathrm{bc}}$ & $16.9^{\mathrm{b}}$ & $21.4^{\mathrm{a}}$ & $12.4^{\mathrm{b}}$ & $11.9^{\mathrm{b}}$ & $11.4^{\mathrm{b}}$ \\
\hline & $17.9^{\mathrm{c}}$ & $23.9^{\mathrm{c}}$ & $8.00^{\mathrm{d}}$ & $48.7^{\mathrm{a}}$ & $8.00^{\mathrm{c}}$ & $32.3^{\mathrm{b}}$ & $8.00^{\mathrm{d}}$ & $26.3^{\mathrm{c}}$ & $23.4^{\mathrm{c}}$ & $5.50^{\mathrm{de}}$ & $10.4^{\mathrm{d}}$ & $9.00^{\mathrm{d}}$ \\
\hline \multirow[t]{2}{*}{ Creamy JAR, \% } & $78.1^{\mathrm{ab}}$ & $60.67^{\mathrm{c}}$ & $85.6^{\mathrm{a}}$ & $46.8^{\mathrm{d}}$ & $85.6^{\mathrm{a}}$ & $60.7^{\mathrm{c}}$ & $85.6^{\mathrm{a}}$ & $64.2^{\mathrm{c}}$ & $43.3^{\mathrm{d}}$ & $84.6^{\mathrm{a}}$ & $75.1^{\mathrm{ab}}$ & $79.1^{\mathrm{ab}}$ \\
\hline & $4.00^{\mathrm{d}}$ & $15.4^{\mathrm{b}}$ & $6.47^{\mathrm{cd}}$ & $4.48^{\mathrm{d}}$ & $6.46^{\mathrm{cd}}$ & $6.97^{\mathrm{cd}}$ & $6.46^{\mathrm{cd}}$ & $9.5^{\mathrm{bc}}$ & $33.4^{\mathrm{a}}$ & $10.0^{\mathrm{bc}}$ & $14.4^{\mathrm{b}}$ & $11.9^{\mathrm{bc}}$ \\
\hline Purchase intent & $3.43^{\mathrm{a}}$ & $2.35^{\mathrm{bc}}$ & $3.09^{\mathrm{ab}}$ & $2.78^{\mathrm{ab}}$ & $3.71^{\mathrm{a}}$ & $2.86^{\mathrm{ab}}$ & $3.73^{\mathrm{a}}$ & $2.04^{\mathrm{d}}$ & $2.18^{\mathrm{d}}$ & $3.70^{\mathrm{a}}$ & $3.34^{\mathrm{a}}$ & $2.57^{\mathrm{ab}}$ \\
\hline
\end{tabular}

${ }^{\mathrm{ag}}$ Different superscript letters within a row following means signify significant differences $(P<0.05)$.

${ }^{1}$ Data represent 201 consumers. Liking attributes were scored on a 9-point hedonic scale, where dislike extremely $=1$ and like extremely $=9$.

${ }^{2}$ Just-about-right (JAR) questions were scored on a 5 -point scale, where too little $=1$ or 2 , just about right $=3$, and too much $=4$ or 5 ; the percentage of consumers that selected these options is presented. Purchase intent was scored on a 5 -point scale, where definitely would not buy $=1$, probably would not buy $=2$, may or may not buy $=3$, probably would buy $=4$, and definitely would buy $=5$.

${ }^{3}$ Full-fat sour cream.

${ }^{4}$ Reduced-fat sour cream.

${ }^{5}$ Light sour cream. 
Table 10. Overall liking means for each cluster $^{1}$

\begin{tabular}{lccc}
\hline Sample & $\begin{array}{c}\text { Cluster 1 } \\
(\mathrm{n}=50)\end{array}$ & $\begin{array}{c}\text { Cluster 2 } \\
(\mathrm{n}=94)\end{array}$ & $\begin{array}{c}\text { Cluster 3 } \\
(\mathrm{n}=57)\end{array}$ \\
\hline $106^{2}$ & $6.9^{\mathrm{a}}$ & $6.9^{\mathrm{a}}$ & $5.8^{\mathrm{e}}$ \\
$111^{2}$ & $6.0^{\mathrm{e}}$ & $6.2^{\mathrm{d}}$ & $4.4^{\mathrm{g}}$ \\
$115^{2}$ & $5.1^{\mathrm{fg}}$ & $5.3^{\mathrm{e}}$ & $5.7^{\mathrm{e}}$ \\
$888^{2}$ & $6.6^{\mathrm{bc}}$ & $6.4^{\mathrm{bc}}$ & $6.9^{\mathrm{a}}$ \\
$969^{3}$ & $3.9^{\mathrm{i}}$ & $5.0^{\mathrm{e}}$ & $6.8^{\mathrm{ab}}$ \\
$885^{3}$ & $4.4^{\mathrm{h}}$ & $3.4^{\mathrm{g}}$ & $5.1^{\mathrm{ef}}$ \\
$222^{4}$ & $5.4^{\mathrm{f}}$ & $4.6^{\mathrm{f}}$ & $3.6^{\mathrm{gh}}$ \\
$996^{2}$ & $6.6^{\mathrm{bc}}$ & $6.6^{\mathrm{b}}$ & $6.0^{\mathrm{d}}$ \\
$363^{2}$ & $6.7^{\mathrm{ab}}$ & $7.1^{\mathrm{a}}$ & $6.4^{\mathrm{c}}$ \\
$789^{2}$ & $6.0^{\mathrm{e}}$ & $6.4^{\mathrm{bc}}$ & $6.1^{\mathrm{d}}$ \\
$753^{2}$ & $6.1^{\mathrm{d}}$ & $3.2^{\mathrm{g}}$ & $6.9^{\mathrm{a}}$ \\
$357^{2}$ & $6.2^{\mathrm{d}}$ & $2.6^{\mathrm{h}}$ & $3.9^{\mathrm{gh}}$ \\
\hline
\end{tabular}

${ }^{\mathrm{a}-\mathrm{i}}$ Means within a column with different superscript letters are statistically different $(P<0.05)$.

${ }^{1}$ Liking attributes were scored on a 9-point hedonic scale, where dislike extremely $=1$ and like extremely $=9$.

${ }^{2}$ Full-fat sour cream.

${ }^{3}$ Light sour cream.

${ }^{4}$ Reduced-fat sour cream.

cream. Three clusters were identified (Table 10). Cluster analysis was confirmed by assessing product attributes and liking of each product by clusters. Sample main effects and sample $\times$ cluster interactions $(F=21.25, P<$ $0.05)$ were observed. The interaction of sample $\times$ cluster suggests that all clusters liked samples differently, further confirming distinct consumer clusters. Cluster 1 (C1) consisted of consumers $(\mathrm{n}=50,25 \%$ of consumers) that liked firm and dense textures and milk fat flavor, and disliked sweet taste in sour cream. Cluster 2 (C2; $\mathrm{n}=94,47 \%$ of consumers) was very similar to $\mathrm{C} 1$ consumers in likes and dislikes. The only difference was that $\mathrm{C} 2$ consumers liked firmness, denseness, and milk fat flavor, as long as it was not overpowering or too strong. Cluster 3 (C3) consumers $(\mathrm{n}=57,28 \%$ of consumers) liked sour creams with sweet aromatic flavor and disliked sour creams high in diacetyl, milk fat, and cooked flavors. Cluster 3 consumers liked reduced-fat sour creams as much as full-fat sour creams and their liking scores for sour creams appeared to be based on flavor attributes rather than a combination of flavor and texture attributes ( $\mathrm{C} 1$ and $\mathrm{C} 2)$. The liking score for reduced-fat sample 969 was 6.8 , whereas the liking scores for full-fat sour creams 888 and 753 were 6.9; these scores were not significantly different and were the top liking scores for this cluster.

Sour creams 106 and 363 were ranked highly among $\mathrm{C} 1$ and $\mathrm{C} 2$ and were not ranked as high by $\mathrm{C} 3$ (Table $10 ; P>0.05)$. Sour creams 106 and 363 were characterized by adhesiveness, milk fat, and diacetyl attributes. Sour creams 753 and 888 received higher liking scores from C3 compared with $\mathrm{C} 1$ and $\mathrm{C} 2$. Sour cream 753 received lower scores from $\mathrm{C} 1$ and $\mathrm{C} 2$. The lower scores from consumers in $\mathrm{C} 1$ and $\mathrm{C} 2$ for samples 885 and 969 were possibly due to the combination of textural attributes for these sour creams (adhesiveness, firmness, and mouthcoating). Sour cream 888 was liked by all clusters; this may be due to this product having a moderate amount of sweet aromatic, sweet taste, sour taste, and the absence of green/acetaldehyde flavor. Sour cream 357 was liked by $\mathrm{C} 1$ consumers and not liked as much by $\mathrm{C} 3$ consumers (Table 10). Sour cream 357 was characterized by sour taste, sour aromatic, denseness, firmness, and mouthcoating. This difference demonstrates that $\mathrm{C} 1$ consumers liked sour taste and sour aromatic flavor more than $\mathrm{C} 2$ and $\mathrm{C} 3$ consumers.

Partial least squares analysis was conducted and variable importance projection (VIP) scores were used to identify drivers of liking (Figures 4 and 5). Drivers of liking for $\mathrm{C} 1$ were cooked/milky, diacetyl, opacity, and milk fat flavors. These drivers explain why $\mathrm{C} 1$ scored samples 106 and 363 as their top choices for sour cream. These samples had the highest intensities of diacetyl and cooked/milky flavor attributes. Drivers of liking for C2 were sweet aromatic, cooked/milky, diacetyl, milk fat, and denseness. Samples 363 and 106 were also the top choices for $\mathrm{C} 2$ as well. Drivers of liking for C3 were milk fat, potato, sweet aromatic, and cooked/sulfurous flavors; these findings confirm the top sour cream choices for C3. Both samples 753 and 888 contained relatively high intensities of cooked/sulfurous attributes.

Drivers of dislike can also be determined from partial least squares analysis. Drivers of dislike for C1 were green/acetaldehyde, cooked/sulfurous, and potato flavors, astringency, sweet taste, sour taste, surface gloss, color intensity, adhesiveness, mouthcoating, and chalkiness. Samples 969 and 885 had a combination of these disliked attributes present at higher intensities and these samples did not contain a perceivable intensity of diacetyl; thus, liking scores for these sour creams were lower for $\mathrm{C} 1$ consumers. Sample 357 had a higher intensity of sour taste; however, it also had a high intensity of sour aromatic, which is a driver of liking for C1. Therefore, consumers in $\mathrm{C} 1$ had a higher liking score for this sour cream than consumers in $\mathrm{C} 2$ and C3. Drivers of dislike for $\mathrm{C} 2$ were sour aromatic, green/acetaldehyde, and potato flavors, astringency, sour taste, color intensity, adhesiveness, and chalkiness. Sample 357 had the highest intensity of green/acetaldehyde and this sample also did not have a perceivable intensity of diacetyl; therefore, this sample received lower liking scores for C2. Drivers of dislike for C3 were diacetyl, sour aromatic, sweet taste, and sour taste. These results suggest that the reason for C3 scoring samples 888 and 753 the highest may be due to the lack of perceivable diacetyl flavor in either sample. Samples 357 and 222 had the lowest 


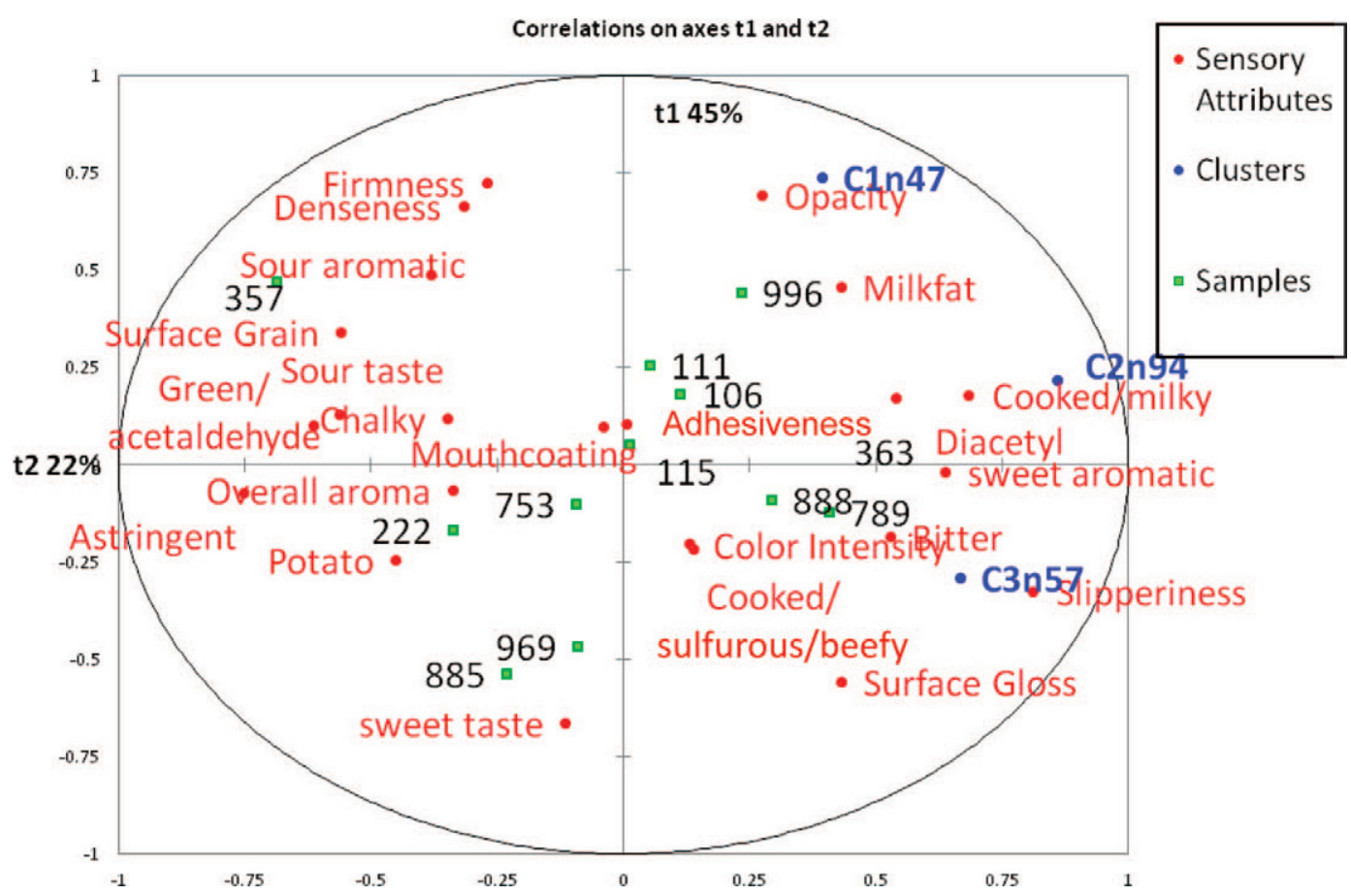

Figure 4. Partial least squares correlation biplot of clusters for sour cream. Numbers represent the sour creams that were included in consumer acceptance tasting. C1 represents cluster $1(\mathrm{n}=50)$; C2 represents cluster $2(\mathrm{n}=94)$; C3 represents cluster 3 ( $\mathrm{n}=57)$. Flavor, texture, and visual attributes are included in this biplot. Sample 222 is reduced fat. Samples 885 and 969 are light sour cream. All other sour creams are full fat. Color version available in the online PDF.

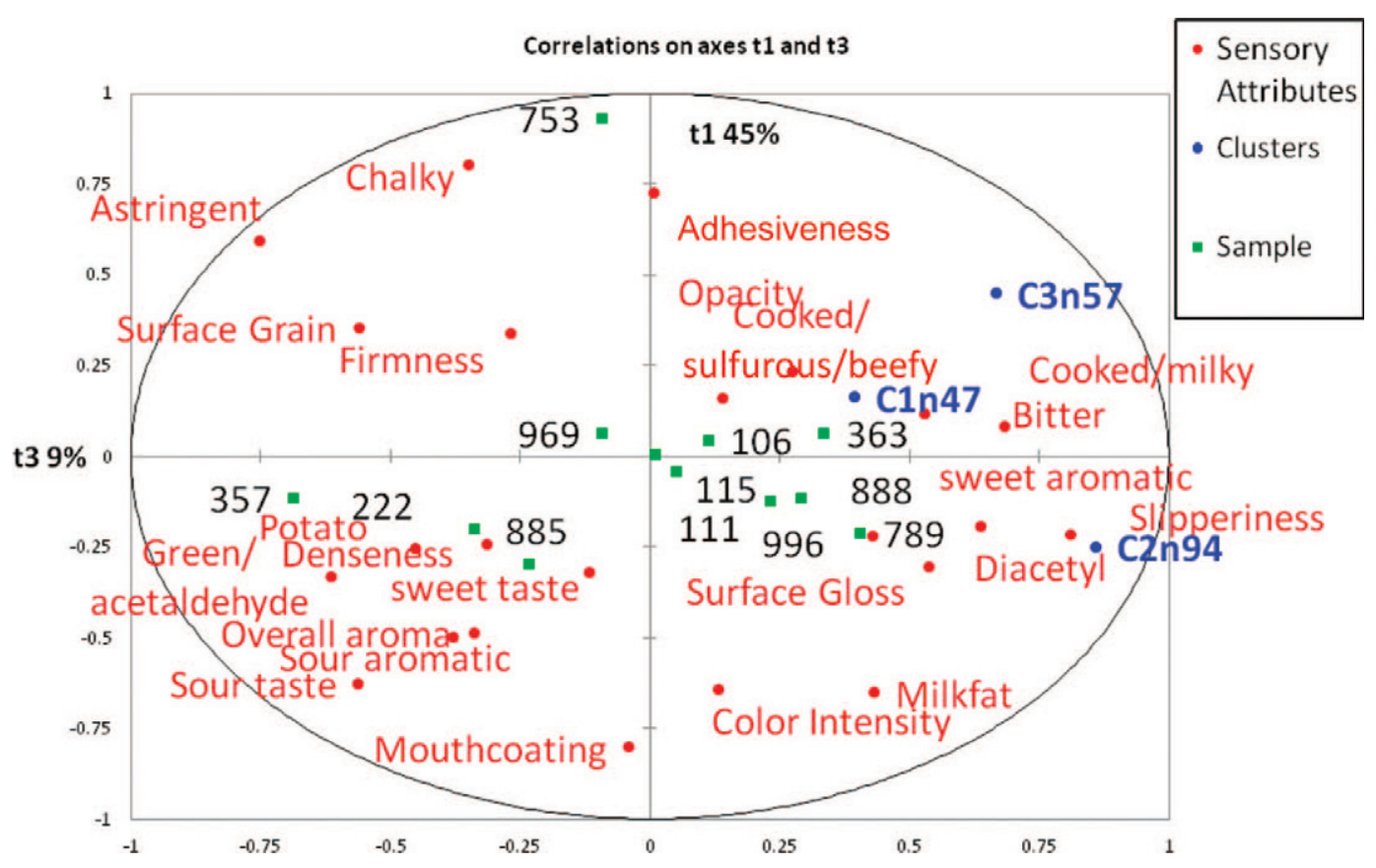

Figure 5. Partial least squares correlation biplot of clusters for sour creams. Numbers represent the sour creams that were included in consumer acceptance tasting. C1 represents cluster $1(\mathrm{n}=50)$; $\mathrm{C} 2$ represents cluster $2(\mathrm{n}=94)$; C3 represents cluster 3 ( $\mathrm{n}=57)$. Flavor, texture, and visual attributes are included in this biplot. Sample 222 is reduced fat. Samples 885 and 969 are light sour cream. All other sour creams are full fat. Color version available in the online PDF. 
scores for C3. Sample 357 had the highest intensity of sour taste among all samples, whereas sample 222 had the highest intensity of sweet taste among all samples. Therefore, these samples had lower liking scores across all consumers.

\section{CONCLUSIONS}

Reduced-fat and fat-free sour creams were characterized by cardboard, sweet taste, potato, and green/ acetaldehyde flavors, whereas full-fat sour creams were characterized by lower intensities or a lack of these flavors. Acetic and lactic acids were present in the majority of the sour creams and contributed to sour taste and sour aromatic flavor. Sour creams that had the highest consumer liking scores (consumers in $\mathrm{C} 1$ and $\mathrm{C} 2$ ) were characteristic of the flavor-active compounds: diacetyl, acetoin, $\delta$-decalactone, and 2-methyl-3-furanthiol. Consumers generally rated full-fat sour creams higher than reduced-fat sour creams. Milk fat was a consistent driver of liking across all clusters, but differences in consumer liking were observed in intensities of milk fat flavor, diacetyl flavor, cooked flavor, sweet taste, firmness, and denseness. Sour taste was a consistent driver of dislike across all clusters, but the ideal intensity of this attribute differed among consumer clusters. Cluster 1 consumers $(n=47)$ were more accepting of a higher intensity of sour taste when combined with a higher intensity of sour aromatic compared with other consumers. Consumers from C3 $(\mathrm{n}=57)$ based their overall liking predominantly on flavor attributes, whereas consumers from $\mathrm{C} 1(\mathrm{n}=47)$ and $\mathrm{C} 2(\mathrm{n}=94)$ based their overall liking on a combination of flavor and texture attributes. Cluster 1 consumers liked sour creams that had higher intensities of opacity, whereas C2 consumers liked sour creams that had higher intensities of denseness. Consumers from $\mathrm{C} 1$ and $\mathrm{C} 2$ disliked the combination of moderate to high intensities of astringency, color intensity, adhesiveness, and chalkiness. A sour cream that would appeal to most consumers is characterized by moderate to high levels of diacetyl, milk fat, and cooked/milky flavors, low to moderate levels of sour taste and sour aromatics, and moderate levels of denseness and firmness. These findings can help manufacturers to manufacture sour creams with optimized sensory properties by altering starter cultures and processing procedures.

\section{ACKNOWLEDGMENTS}

Funding was provided in part by the Dairy Research Institute (Rosemont, IL). The use of trade names does not imply endorsement nor a lack of endorsement by those not mentioned.

\section{REFERENCES}

Bevilacqua, A. E., and A. N. Califano. 1989. Determination of organic acids in dairy products by high performance liquid chromatography. J. Food Sci. 54:1076.

Brauss, M. S., R. S. T. Linforth, I. Cayeux, B. Harvey, and A. J. Taylor. 1999. Altering the fat content affects flavor release in a model yogurt system. J. Agric. Food Chem. 47:2055-2059.

Cadwallader, K. R., and T. K. Singh. 2009. Flavours and off-flavours in milk and dairy products. Adv. Dairy Chem. 3:631-690.

Carunchia Whetstine, M. E., A. E. Croissant, and M. A. Drake. 2005. Characterization of dried whey protein concentrate and isolate flavor. J. Dairy Sci. 88:3826-3839.

Carunchia-Whetstine, M. E., Y. Karagul-Yuceer, Y. K. Avsar, and M. A. Drake. 2003. Aroma-active compounds in fresh goat cheese. J. Food Sci. 68:2441-2447.

Dellaglio, F. 1988. Starters for fermented milks. IDF Bull. 227:27-34

Drake, S. L., P. D. Gerard, and M. A. Drake. 2008. Consumer preferences for mild Cheddar cheese flavors. J. Food Sci. 73:S449-S455.

Drake, S. L., K. Lopetcharat, and M. A. Drake. 2009. Comparison of two methods to explore consumer preferences for cottage cheese. J. Dairy Sci. 92:5883-5897.

Driessen, F. M., and Z. Puhan. 1988. Technology of mesophilic fermented milk. IDF Bull. 227:75-81.

Fernandez-Garcia, E., and J. U. McGregor. 1994. Determination of organic acids during the fermentation and cold storage of yogurt. J. Dairy Sci. 77:2934-2939.

Foegeding, E. A., and M. A. Drake. 2007. Sensory and mechanical properties of cheese texture. J. Dairy Sci. 90:1611-1624.

Hatanaka, H., and Y. Kaneda. 1986. Rapid and simultaneous analysis of hippuric and benzoic acids in fermented milk or raw milk by high performance liquid chromatography. J. Food Hyg. Soc. Jpn. $27: 81-86$.

Heiler, C., and P. Schieberle. 1996. Studies on the metallic off-flavour in buttermilk: Identification of potent aroma compounds. Lebensm. Wiss. Technol. 29:460-464.

Izco, J. M., M. Tormo, and R. Jiménez-Flores. 2002. Rapid simultaneous determination of organic acids, free amino acids, and lactose in cheese by capillary electrophoresis. J. Dairy Sci. 85:2122-2129.

Kim, M. K., S. L. Drake, and M. A. Drake., 2011. Evaluation of key flavor compounds in reduced- and full-fat Cheddar cheeses using sensory studies on model systems. J. Sens. Stud. 26:278-290.

Marsili, R. T., H. Ostapenko, R. E. Simmons, and D. E. Green. 1981. High performance liquid chromatographic determination of organic acids in dairy products. J. Food Sci. 46:52-57.

Meilgaard, M., G. V. Civille, and B. T. Carr. 1999. Sensory Evaluation Techniques. 3rd ed. CRC Press Inc., Boca Raton, FL.

Meilgaard, M., G. V. Civille, and B. T. Carr. 2007. Advanced statistical methods: Preference mapping. Pages 391-404 in Sensory Evaluation Techniques. 4th ed. CRC Press Inc., Boca Raton, FL.

Meunier-Goddik, L. 2004. Semisolid cultured dairy products: Sour cream and crème fraîche. Pages 171-183 in Handbook of Food and Beverage Fermentation Technology. Y. H. Hui, L. MeunierGoddik, Å. S. Hansen, J. Josephsen, W.-K. Nip, P. S. Stanfield, and F. Toldrá, ed. Marcel Dekker Inc., New York, NY

Nozière, P., B. Graulet, A. Lucas, B. Martin, P. Grolier, and M. Doreau. 2006. Carotenoids for ruminants: From forages to dairy products. Anim. Feed Sci. Technol. 131:418-450.

Relkin, P., M. Fabre, and E. Guichard. 2004. Effect of fat nature and aroma compound hydrophobicity on flavor release from complex food emulsions. J. Agric. Food Chem. 52:6257-6263.

Rysstad, G., and R. K. Abrahamsen. 1987. Formation of volatile aroma compounds and carbon dioxide in yogurt starter grown in cows' and goats' milk. J. Dairy Res. 54:257-266.

Serra, M., A. J. Trujillo, B. Guamis, and V. Ferragut. 2009. Flavour profiles and survival of starter cultures of yoghurt produced from high-pressure homogenized milk. Int. Dairy J. 19:100-106.

Singh, T. K., M. A. Drake, and K. R. Cadwallader. 2003. Flavor of Cheddar cheese: A chemical and sensory perspective. Compr. Rev. Food Sci. Food Safety 2:139-162. 
Smit, G., B. A. Smit, and W. J. M. Engels. 2005. Flavour formation by lactic acid bacteria and biochemical flavor profiling of cheese products. FEMS Microbiol. Rev. 29:591-610.

Swaney-Stueve, M., and H. Heymann. 2002. A comparison between paper and computerized ballots and a study of simulated substitution between the two ballots used in descriptive analysis. J. Sens. Stud. 17:527-537.

Thompson, J. L., M. Lopetcharat, and M. A. Drake. 2007. Preferences for commercial strawberry drinkable yogurts among African American, Caucasian, and Hispanic consumers in the United States. J. Dairy Sci. 90:4974-4987.

Tormo, M., and J. M. Izco. 2004. Alternative reversed-phase high-performance liquid chromatography method to analyze organic acids in dairy products. J. Chromatogr. A 1033:305-310.

USDA-AMS (US Department of Agriculture Agricultural Marketing Service). 2005. Specifications for sour cream and acidified sour cream June 5, 2005. Accessed Sep. 27, 2011. http://www.ams. usda.gov/AMSv1.0/getfile?dDocName=STELDEV30004552.

USDA-NASS (US Department of Agriculture National Agricultural Statistics Service). 2010. Dairy products: April 2013 highlights. Accessed Sep. 27, 2011. http://nass.usda.gov/Publications/Todays_Reports/reports/dary0613.pdf.

US FDA (US Food and Drug Administration). 2011. Code of Federal Regulations. Title 21, Vol. 2. 21CFR 131.160. Food and Drugs. US Government Printing Office. Accessed July 5, 2011. http://www. accessdata.fda.gov/scripts/cdrh/cfdocs/cfcfr/CFRSearch.cfm?fr= 131.160 .
Urbienè, S., and D. Leskauskaitè. 2006. Formation of some organic acids during fermentation of milk. Pol. J. Food Nutr. Sci. 15/56:277-281.

van Den Dool, H., and P. D. Kratz. 1963. A generalization of the retention index system including linear programmed gas-liquid partition chromatography. J. Chromatogr. A 11:463-471.

van Gemert, L. J. 2003. Flavour Thresholds: Compilations of Flavour Threshold Values in Water and Other Media. Oliemans Punter \& Partners BV, Utrecht, the Netherlands.

Wehr, H. M., and J. F. Frank. 2004. Pages 380-382, 427-434, 440-441, 447-449, and 480-495. Standard Methods for the Examination of Dairy Products. American Public Health Association, Washington, DC.

Whitson, M. E., R. E. Miracle, and M. A. Drake. 2010. Sensory characterization of chemical components responsible for cardboard flavor in whey protein. J. Sens. Stud. 25:616-636.

Yates, M. D., and M. A. Drake. 2007. Texture properties of Gouda cheese. J. Sens. Stud. 22:493-506.

Zhang, C., H. Yang, F. Yang, and Y. Ma. 2009. Current progress on butyric acid production by fermentation. Curr. Microbiol. 59:656-663.

Zhang, H., and L. E. Metzger. 2010. Chemistry and biochemistry: Organic acids. Pages 259-276 in Handbook of Dairy Food Analysis. L. M. L. Nollet and F. Toldrá, ed. CRC Press Inc., Baca Raton, FL. 